\title{
The Informational Efficiency of the Equity Market As Compared to the Syndicated Bank Loan Market
}

\author{
Linda Allen \\ Professor of Finance \\ Baruch College, CUNY \\ Linda_Allen@baruch.cuny.edu \\ Aron A. Gottesman \\ Assistant Professor of Finance \\ Lubin School of Business, Pace University \\ agottesman@pace.edu
}

August 2004

\begin{abstract}
$\underline{\text { Abstract }}$
To our knowledge, this is the first paper to examine the informational efficiency of the equity market as compared to the syndicated bank loan market. The loan market is a private market comprised of financial institutions with access to private information. We test whether this is reflected in informationally efficient price formation in the loan market vis a vis the equity markets, and reject this private information hypothesis. We find support for a liquidity hypothesis, suggesting that equity markets lead loan markets, despite bank lenders' access to private information, because of greater liquidity in equity markets. Only when equity markets are relatively illiquid do we find evidence supporting the private information hypothesis. Finally, we find evidence of abnormal returns if portfolios are constructed using lagged equity returns to designate investments in the syndicated bank loan market.
\end{abstract}




\section{The Informational Efficiency of the Equity Market As Compared to the Syndicated Bank Loan Market}

\section{Introduction}

A firm generally issues several types of securities, each of which represents some claim on the firm's assets. If capital markets are perfect and frictionless, then all information about the value of the firm's assets is reflected immediately into the prices of each of the firm's securities. However, capital markets are neither perfect nor frictionless. Different markets have access to different types of firm-specific information. Traders may prefer one market venue to another. The price formation system may differ in efficiency across markets. These market imperfections may prevent the integration of securities markets in incorporating all available information about the value of the firm's assets. In this paper, we compare the relationship between equity returns and the contemporaneous and lagged returns on secondary market prices of bank debt in order to test the integration between the equity and bank loan markets. Moreover, we reverse our tests and examine the relation between loan returns and contemporaneous and lagged equity returns. We employ Granger causality tests to compare each market's impact on the other.

During the mid-1990s, a relatively liquid secondary market developed for a segment of the bank debt market: syndicated bank loans. Thomas and Wang (2004) find that by the year 1994, the leveraged loan market had developed to such a point that junk bond yields and spreads on bank loans were determined by the same underlying firm-specific and market liquidity factors. ${ }^{1}$ The development of this liquid securities market may have spillover information effects for other markets, such as publicly traded debt and equity. This is particularly relevant since

\footnotetext{
${ }^{1}$ Leveraged loans are non-investment grade loans made to highly leveraged borrowers. They are priced at spreads that exceed 200 basis points over LIBOR.
} 
syndicated bank loans are underwritten by groups of informed lenders that may have access to the regular receipt of private information obtained in response to loan covenants that require the borrowing firm to release detailed financial and accounting data to the loan syndicate. Moreover, the syndicate is typically led by a lead arranger or a lead bank that has gathered a considerable amount of private information about the borrowing firm in the course of a long term banking relationship. Thus, Altman, Gande and Saunders (2003) find that the syndicated bank loan market is more informationally efficient than the bond market, such that default events are more rapidly incorporated into loan prices than bond prices. The finding of greater informational efficiency in the syndicated bank loan market is denoted the private information hypothesis.

However, debt markets in general, and syndicated bank loan markets in particular, are considerably less liquid than public equity markets. ${ }^{2}$ Thus, although lenders may have access to superior information, noise in the price formation process in the syndicated bank loan market may hamper informational efficiency. We denote this the liquidity hypothesis. Thus, Kwan (1996) finds that the stock market is more informationally efficient than the bond market. Moreover, Hotchkiss and Ronen (2002) find that neither the bond nor the stock market lead each other in incorporating firm-specific information, but appear to be contemporaneously reacting to common factors.

In this paper, we compare the level of information integration in the equity market to that of the syndicated bank loan market. To our knowledge, this is the first paper to compare the informational efficiency of public equity to private debt markets. Public debt holders tend to have access to the same set of information about the firm as do public equity holders, thereby

\footnotetext{
${ }^{2}$ Most debt instruments trade over the counter in a negotiated interdealer market. Saunders, Srinivasan and Walter (2002) show that the corporate bond market is characterized by large spreads and infrequent trades. See Saunders and Allen (2002), chapter 5, for a discussion of illiquidity factors in bond markets.
} 
suggesting that bond returns and stock returns reflect the same firm-specific information. However, information flows differently in private as opposed to public debt markets. ${ }^{3}$ Thus, we examine whether the private information hypothesis or the liquidity hypothesis dominates in equity and syndicated bank loan markets.

Our findings suggest that the liquidity hypothesis dominates the private information hypothesis over our sample period, ranging from 1999 to 2003 . We compare the price formation process in both markets and find that loan returns are related to lagged and contemporaneous equity returns, whereas equity returns are generally unrelated to either lagged or contemporaneous loan returns. We utilize Granger causality tests to verify that loan returns incorporate lagged stock returns, but stock returns do not generally reflect loan returns. We also document the presence of significant abnormal returns when lagged equity returns are used to design an investment strategy in the syndicated bank loan market. There is one important exception to this finding. For relatively illiquid equity issues (i.e., that have a low volume of transactions), we find that lagged loan returns Granger cause equity returns, as well as lagged equity returns Granger cause loan returns. Thus, when the liquidity hypothesis does not hold, we find evidence in support of the private information hypothesis.

The paper is organized as follows. In Section 2, we construct portfolios using our sample of 45,586 weekly loan and equity returns in order to examine the integration of loan and equity returns. We test the cross-correlations across markets using Granger causality tests and search for the presence of abnormal returns resulting from predictability across markets. In Section 3, we segment the sample in order to test the private information hypothesis with subsamples of informationally intensive loans. We also create liquidity-constrained subsamples in order to test

\footnotetext{
${ }^{3}$ For a survey of the literature on bank loans as privately placed debt, see Boot (2000).
} 
the liquidity hypothesis more directly. In Section 4, we define borrower- and loan-specific factors and test the impact of these factors on the degree and direction of market integration. The paper concludes in Section 5.

\section{Testing the Integration Between the Loan and the Equity Markets}

There is a fairly extensive literature comparing the informational efficiency of the bond market to the stock market. For example, Keim and Stambaugh (1986), Campbell (1987) and Campbell and Ammer (1993) examine the problem in the aggregate. Kwan (1996) examines the relative informational efficiency of the stock and bond market for individual firms. Hotchkiss and Ronen (2002) examine the question using intraday data. However, there has been virtually no work examining the integration of the equity and bank loan markets. ${ }^{4}$

There are two major distinguishing features differentiating equity from bank loan markets. First, bank loans are debt instruments, and may therefore be less sensitive than equity to firm-specific information because of debt's contractual limitation on the potential for upside gain. Second, bank loans are private debt instruments, and therefore have different information and liquidity features than publicly traded debt or equity. A literature has developed comparing the informational efficiency of public debt to public equity markets, but there has been virtually no work on the efficiency of integration of public and private financial markets.

Cornell and Green (1991) and Blume, Keim and Patel (1991) were among the first to examine the pricing performance of below-investment grade corporate bonds relative to high

\footnotetext{
${ }^{4}$ Dahiya, Puri and Saunders (2003) examine the reaction of stock prices to bank loan sales and find that stock returns are negatively impacted by the announcement of a loan sale. Allen, Guo and Weintrop (2004) find that earnings announcements are reflected more rapidly in bank loan prices than in stock prices. These results suggest that information about firm-specific events (e.g., loan sales or earnings announcements) is incorporated in the bank loan market and transmitted to the stock market. However, they are not tests of cointegration across markets.
} 
grade corporate bonds and stocks. ${ }^{5}$ Cornell and Green (1990) use mutual fund data and find that the market for low-grade corporate bonds is as efficient as the market for high-grade bonds. Similarly, Blume, Keim and Patel (1991) use individual bond data and find that the price formation process in below investment grade bond markets is as efficient as high grade bond and stock markets. However, these studies do not explicitly test for informational efficiency. Kwan (1996) rectifies this and employs cointegration tests of whether contemporaneous and lagged stock returns explain bond returns. He finds evidence of significant coefficients on lagged stock returns for both investment grade and below investment grade bonds, suggesting that the stock market leads the bond market. ${ }^{6}$ However, Hotchkiss and Ronen (2002) refute this result, using intraday data on individual high yield bonds that trade on NASD's Fixed Income Pricing System (FIPS). This relatively liquid corporate bond market displays greater informational efficiency than found in Kwan's sample. Although Hotchkiss and Ronen (2002) do not test it directly, their results offer support for the liquidity hypothesis, since they find informational efficiency for the liquid corporate bonds in their sample. However, neither Kwan (1996) nor Hotchkiss and Ronen (2002) reverse their model specification in order to explicitly test whether lagged bond returns can explain stock returns. We perform that analysis in this paper using returns on syndicated bank loans.

The syndicated bank loan market is actually a hybrid between publicly traded debt (corporate bonds) and privately held (non-traded) bank loans. Trading in the syndicated bank loan market is limited to financial institutions and sophisticated investors as a result of the

\footnotetext{
${ }^{5}$ Many syndicated bank loans are below investment grade either from initiation (i.e., leveraged loans that have debt to cash flow ratios exceeding 4:1) or as a result of deterioration over time in the loan's credit quality ("fallen angels").

${ }^{6}$ The exception to the finding that lagged stock returns explain bond returns in Kwan (1996) is for AAA-rated corporate bonds, which depend more on the risk free rate than on firm-specific information. However, Hotchkiss and Ronen (2002) find that the distinction between high grade and low-grade bonds is only weakly significant.
} 
designation of these instruments as Rule 144a securities. This limits market liquidity, but also restricts the amount of noise trading in the bank loan market. Participants include banks, as well as non-bank financial intermediaries. ${ }^{7}$ To the extent that many bank loans contain covenants requiring the borrower to transfer detailed financial information to loan syndicate members on a regular basis, the information features of the bank loan market make it more informationally efficient than the bond market. ${ }^{8}$ The question that our paper addresses is whether the loan market is more informationally efficient than the stock market.

\subsection{Data}

We obtain a sample of secondary market data from the Loan Pricing Corporation (LPC) that consists of the average bid and average ask quotations on all syndicated bank loans that had at least 2 quotes for any week during the January 1999 through May 2003 period. A total of 129,172 observations met these criteria, associated with 1,621 loan facilities to 763 borrowers.

For each observation for which the previous week's loan price is available for the loan facility, we calculate the weekly loan return, $R B_{t}$, using the average of the mean bid and mean ask quotation as a proxy for loan transaction price. ${ }^{9}$ We next extract from CRSP weekly equity returns that correspond to the weekly loan returns. Through the comparison of tickers and names, we identify 357 of the 763 borrowers on CRSP. Weekly equity price information is available for 352 of these 357 borrowers during our sample period. We use this weekly information to calculate weekly equity returns, denoted $R S_{t}$, after standardizing the price by the cumulative factor to adjust for splits and dividends. After eliminating any observation for which the return

\footnotetext{
${ }^{7}$ A trade study by Paine Webber shows that, as of 1998 , more than $40 \%$ of the syndicated bank loan facilities were comprised of non-bank financial institutions, with $26 \%$ of the loans held by bank loan mutual funds and $5 \%$ held by insurance companies.

${ }^{8}$ Bradley and Roberts (2004) find that a loan is more likely to include covenants if the borrower is small, highly leveraged, and relies on intangible growth opportunities for firm value.

9 There is no "tape" of transaction prices in the negotiated secondary market for bank loans. We use the average of the bid and ask quotations as an estimate of the transaction price.
} 
information is unavailable, we are left with 50,244 observations, associated with 772 loan facilities to 352 borrowers.

We also extract the S\&P 500 Composite Index from CRSP and calculate the weekly equity index return, $R M_{t}$, for each observation. Using the $\mathrm{S} \& \mathrm{P} / \mathrm{LSTA}$ syndicated bank loan index, we calculate the weekly loan index return, $R L_{t}$, for each observation. ${ }^{10}$ Finally, we obtain the annualized 3-month secondary market T-Bill rates from the Federal Reserve Bank of St. Louis as of the date of each observation to the observation date and calculate the weekly 3-month T-Bill rate, $R D_{t}$.

For each week during our sample period, we form equally weighted portfolios of equity and loan returns consisting of all observations for which all variables, including lags, are available for the week. To perform the integration tests, we test several price formation models, incorporating lagged equity (loan) returns ranging from one (zero) week lags to four (three) week lags. The number of weekly portfolio observations ranged from 185 (for the model with four weeks of equity lags) to 200 (for the model incorporating only one week of lagged equity returns). We report the results of the model using two weeks of lagged equity returns and one week of lagged loan returns, resulting in a sample size of 194 weekly portfolio observations comprising 45,586 individual loan and equity returns. ${ }^{11}$

As the descriptive statistics in Table I show, the average loan return is negative over the sample period (a mean of $-0.08 \%$, statistically different from zero at the $1 \%$ level of significance of the t-test). This is most likely the outgrowth of the sample period, a considerable portion of

${ }^{10}$ LSTA, in conjunction with Standard \& Poor's, maintains a weekly index of senior bank loan prices. The S\&P/LSTA syndicated bank loan index currently includes 470 loan facilities totaling \$104 billion in value outstanding, covering around $70 \%$ of the institutional loan market. Starting in January 1999, the S\&P leverage loan index provides weekly quotes on the syndicated loan market index.

${ }^{11}$ Our results are extremely robust to all lag structures, and are available from the authors upon request. 
which coincided with a recession, the deepening of liquidity discounts, declining loan prices and a large group of "fallen angels," i.e., distressed loans that formerly traded at or around par.

In addition to the measures of return described above, we also identify the year of each observation, denoted $Y_{t}$; the sum of the number of bid and ask quotations for the loan $i$ on the secondary loan market for the date $t$ of the observation, denoted $N B A_{i t}$; the difference between the average ask and average bid loan $i$ price on the date $t$ of the observation, denoted $S P R D_{i t}$; and the volume of trades in the equity market for borrower $i$ on the date $t$ of the observation, denoted $V_{t}$. Table I reports that the average number of loan quotes in our sample is greater than 8 , the average bid/ask loan spread is 164 basis points, and the average volume of equity transactions is approximately 931,400 for our sample observations.

\subsection{Cointegration Tests}

In this section we examine the relation between loan and equity returns. We use the Generalized Method of Moments to estimate the following return-generating processes:

$$
\begin{aligned}
& R B_{t}=\alpha_{t}+\beta_{1}^{B} R B_{t-1}+\sum_{i=0}^{2} \beta_{i}^{S} R S_{t-i}+\sum_{i=0}^{2} \beta_{i}^{M} R M_{t-i}+\beta_{0}^{L} R L_{t}+\beta_{0}^{D} R D_{t}+Y_{t}+N B A_{t}+S P R D_{t}+V_{t}+\varepsilon_{t}, \\
& R S_{t}=\alpha_{t}+\sum_{i=0}^{1} \beta_{i}^{B} R B_{t-i}+\sum_{i=1}^{2} \beta_{i}^{S} R S_{t-i}+\sum_{i=0}^{2} \beta_{i}^{M} R M_{t-i}+\beta_{0}^{L} R L_{t}+\beta_{0}^{D} R D_{t}+Y_{t}+N B A_{t}+S P R D_{t}+V_{t}+\varepsilon_{t},
\end{aligned}
$$

This specification is similar to the cointegration tests specified in Hotchkiss and Ronen (2002). ${ }^{12}$

Table II reports the results of estimation of the processes specified in equations (1) and (2). The results indicate that the equity market leads the loan market in incorporating firmspecific information. The estimation of equation (1) results in a statistically significant (at the 5\%

\footnotetext{
${ }^{12}$ One notable distinction between our model and Hotchkiss and Ronen (2002) is that we include both the loan index return and US Treasury bill rate in the same model, whereas Hotchkiss and Ronen (2002) alternate between these two variables. Our tests are robust to the exclusion of either loan index return or the T-Bill rate.
} 
level) coefficient on lagged equity returns $\left(R S_{t-1}\right)$ in explaining loan returns. However, the estimation of equation (2) shows that lagged and contemporaneous loan returns do not have a statistically significant impact on equity returns. Thus, equity returns have explanatory power in determining loan returns, but loan returns have no explanatory power with regard to equity returns. These results support the liquidity hypothesis and refute the private information hypothesis. ${ }^{13}$ Other results of the estimation are unsurprising. For each regression, the respective index has statistically significant explanatory power on the contemporaneous index, whether the loan index, $R L_{t}$ for equation (1) or the $\mathrm{S} \& \mathrm{P} 500$ index, $R M_{t}$ for equation (2).

\subsection{Causality}

In this section, we test whether we can identify evidence of Granger causality (Granger (1969), Sims (1972)) in the relationship between loan and equity returns. We use the Bivariate Granger Causality Test to separately test whether we can reject the null hypothesis that equity returns do not Granger cause loan returns, and whether we can reject the null hypothesis that loan returns do not Granger cause equity returns. We implement the tests through OLS estimating the following models:

$$
\begin{aligned}
& R B_{t}=\alpha_{t}+\beta_{1} R B_{t-1}+\beta_{2} R S_{t-1}+\varepsilon_{t}, \\
& R S_{t}=\alpha_{t}+\beta_{1} R S_{t-1}+\beta_{2} R B_{t-1}+\varepsilon_{t} .
\end{aligned}
$$

where $\beta_{1}$ and $\beta_{2}$ are coefficients. Each model is estimated twice. First, the restricted estimation excludes the variables $R S_{t-1}$ and $R B_{t-1}$ from equations (3) and (4), respectively. Second, the unrestricted estimation of equations (3) and (4) is performed without excluding any variables.

\footnotetext{
${ }^{13}$ These results are robust to all model specifications and lag structures. We find strong evidence of a relationship between lagged equity returns and loan returns, but not of a relationship between lagged loan returns and equity returns.
} 
Comparing the sum of squared residuals for the unrestricted and restricted models, we conduct $F$-tests and asymptotically equivalent tests of the null hypothesis that $\beta_{2}=0$ in equations (3) and (4). The results of the tests of whether we can reject the null hypothesis that equity returns do not Granger cause loan returns are reported in the first Column of Table III, whereas the results of the Granger causality test of the null hypothesis that loan returns do not cause equity returns are reported in the second Column of Table III.

The results of the Granger tests of equation (3) reject the null hypothesis using both the $F$-test and the asymptotically equivalent test. ${ }^{14}$ The value of the $F$-test statistic is 29.5525 , whereas the value of the asymptotically equivalent test statistic is 30.0167 , both significant at the $1 \%$ level. Thus, the results of Column (1) of Table III suggest that equity returns Granger cause loan returns.

The results of the Granger causality tests of equation (4) fail to reject the null hypothesis using both the $F$-test and the asymptotically equivalent test. The value of the $F$-test statistic is 1.1727, whereas the value of the asymptotically equivalent test statistic is 1.1911 , both statistically insignificant. Thus, the results of Column (2) of Table III do not support the contention that equity returns are Granger caused by loan returns. Both sets of Granger causality test results, therefore, support the liquidity hypothesis and refute the private information hypothesis.

\subsection{Abnormal Portfolio Returns}

In Section 2.2, we demonstrate that the equity returns lead loan returns, but not vice versa. In Section 2.3, we demonstrate that equity returns Granger cause loan returns, but loan returns do not Granger cause equity returns. These results imply rejection of the private

\footnotetext{
14 These results are robust to model specification and lag structure.
} 
information hypothesis in favor of the liquidity hypothesis. Moreover, they suggest predictability in loan returns that may be used to generate abnormal portfolio returns. Therefore, as another test of the results in Sections 2.2 and 2.3, we construct portfolios based on lagged returns and test for possible arbitrage opportunities resulting from predictability in pricing across the bank loan and equity markets.

For every week in the time period, we separately form equally weighted portfolios consisting of loan (equity) return observations for which the lagged equity (loan) return in excess of the T-bill return is positive or negative. We then subtract the loan (equity) return on the negative lagged equity (loan) portfolio from the return on the positive lagged equity (loan) to simulate a portfolio consisting of long positions in loans (stocks) with positive lagged equity (loan) returns and short positions in loans (stocks) with negative lagged equity (loan) returns. Thus, we test whether one could earn abnormal returns in the loan market by buying loans with positive lagged equity returns and selling loans with negative lagged equity returns. In addition, we test whether one could earn abnormal returns in the equity market by trading on loan return information; that is, buying stocks with positive lagged loan returns and selling stocks with negative lagged loan returns.

To test whether this investment strategy can generate abnormal returns, we first report the mean weekly return on the long/short portfolio returns in excess of US Treasury bill rates over the sample period. Table IV presents these results. The top panel of Table IV examines whether abnormal returns can be earned by using lagged equity returns to construct loan portfolios. We find evidence of significant (at the 5\% level) abnormal returns, averaging 6 basis points per week, supporting our earlier findings that the equity market leads the loan market. Thus, information about equity returns can be profitably used to trade in the loan market. 
We also use a single factor model to regress excess returns on the constructed long/short loan portfolio against excess loan index returns. The intercept of this regression should denote abnormal returns on the portfolio. The top panel of Table IV presents an intercept (alpha) term of almost 5 basis points (significant at the $10.12 \%$ level). This suggests the presence of abnormal returns when constructing portfolios of loans using lagged equity returns.

We find no evidence of abnormal returns in the equity market. That is, we test an investment strategy using lagged loan returns to design equity portfolios, such that the portfolio is rebalanced each week to buy stocks with positive lagged loan returns and sell stocks with negative lagged loan returns. The bottom panel of Table IV reports that the average return on these portfolios is insignificantly different from zero. Moreover, using a single index model of excess equity returns on excess equity market returns, we find that the intercept term (alpha) is insignificantly different from zero. Thus, we find no evidence that loan returns have power in explaining equity returns. Using these three different approaches (integration tests, Granger causality tests and measures of potential abnormal returns), we conclude that the equity market is more informationally efficient than the loan market.

\section{Direct Tests of the Liquidity and Private Information Hypotheses}

The results of the tests reported in Section 2 provide support for the liquidity hypothesis over the private information hypothesis in that we find that the more liquid equity markets tend to lead the more informationally-intensive loan markets. However, we have not tested these hypotheses directly. In this section, we divide our sample of 45,586 individual weekly loan and equity returns into various subsamples in order to construct weekly portfolios that differ systematically on the basis of liquidity and information content. For each criterion, we split the 
sample in half using the sample median to construct subsamples. ${ }^{15}$ Thus, for example, the entire sample has a median of 8 loan quotes. Therefore, in Tables V-VII, the low (high) number of loan quotes subsample comprises the observations with less than (more than) 8 bid plus ask quotations. Each of the subsamples in Tables V-VII is similarly defined.

\subsection{Testing the Private Information Hypothesis}

Private firm-specific information is obtained by the members of the syndicate in the course of the lending relationship. It is the function of the lead bank to monitor the activities of the borrower in order to continually update the syndicate on the quality of the loan. Moreover, many bank loans require the regular transfer of detailed financial information in order to check on the borrower's compliance with specific loan covenants. This feature allows greater flexibility in syndicated bank loans than in publicly traded debt. For example, borrowers in financial distress often renegotiate their bank debt, thereby avoiding the deadweight costs of default and bankruptcy that are more prevalent for publicly held bonds. Renegotiation is often triggered by the breaching of covenants that dictate rules defining the borrower's technical default of the loan agreement.

There are two major types of covenants: financial covenants and general covenants. Financial covenants institute rules that circumscribe the borrower's financial performance. General covenants institute behavioral rules that bind the borrower. Since financial covenants relate to accounting variables and firm financial ratios, monitoring compliance requires regular (usually monthly) reports of private firm-specific information. In our database, the most prevalent financial covenant is a restriction on the maximum debt to EBITDA ratio (i.e., total

\footnotetext{
${ }^{15}$ Table I presents median values for the constructed portfolios. In this section, we determine the median associated with the individual observations database comprised of the pooled time series cross sectional data. We then construct portfolios for each subsample separately. There are slight differences between portfolio medians (reported in Table I) and pooled sample medians.
} 
debt divided by cash flow as measured by net income plus depreciation and other non-cash charges). Thus, all borrowers with a debt to EBITDA covenant in their bank loans would be required to submit a statement of EBITDA and debt outstanding on a monthly basis to the loan syndicate. ${ }^{16}$ Other common covenants are a net worth requirement, tangible net worth requirement, and current ratio covenant. All require regular reporting of sensitive financial data to the members of the syndicate. To reflect this private information, we segment our sample into those loans that have financial covenants and those that do not.

We construct two sets of portfolios, consisting of loans with and without financial covenants, and calculate weekly portfolio returns for both equity and loan markets. These returns are then used to re-estimate equations (1) and (2) to test for integration between the loan and equity markets. Table V presents the results of the GMM estimation of equation (1) for each subsample, to test whether lagged equity returns can explain loan returns. Column (7) of Table V reports the results for the more informationally intensive subsample of loans with financial covenants, as compared to Column (8) that shows the loans without financial covenants. Lagged equity returns have significant (at the $5 \%$ level or better) coefficients in explaining loan returns for the subsample of loans with financial covenants, whereas the equity return coefficients are insignificant for the subsample of loans without financial covenants. Thus, equity returns lead loan returns for the informationally intensive subsample, a result that is inconsistent with the private information hypothesis that would suggest that loan returns lead equity returns for this subsample. Moreover, Table VI presents the results of the GMM estimation of equation (2) testing whether lagged loan returns can explain equity returns for each subsample of the database - column (7) for the informationally intensive sample of loans with financial covenants and

\footnotetext{
${ }^{16}$ Allen, Guo and Weintrop (2004) find evidence of this monthly timing in the information content of earnings announcements.
} 
column (8) for those loans without financial covenants. There is no evidence in the estimated coefficients in columns (7) and (8) in Table VI in support of the private information hypothesis. Both contemporaneous and lagged loan returns have insignificant coefficients for both subsamples of loans with and without financial covenants, suggesting that the private information transmitted in compliance with loan covenants does not cause loan returns to lead (or explain) equity returns.

Industry convention is to designate distressed loans as loans trading at prices of 70 or below. These are the loans that are in imminent danger of default and would consequently generate the most intensive monitoring by bank lenders. Thus, banks should have more private information for the distressed loan subsample than for the subsample of par loans (trading at 90 or above). Thus, the private information hypothesis would anticipate that the lagged loan returns would have more explanatory power in determining equity returns for the distressed subsample as compared to the par loan subsample. Columns (5) and (6) in Tables V and VI show that this is not the case, thereby refuting the private information hypothesis. Lagged equity returns have significant (at the 1\% level) coefficients in Column (5) of Table V for distressed loan portfolio returns, but not for par loan portfolios in Column (6), suggesting that equity markets lead loan markets in the information-intensive distressed loan subsample. Moreover, Columns (5) and (6) of Table VI show that lagged loan returns have no explanatory power for equity returns. Thus, the results in Tables V and VI offer no support for the private information hypothesis.

\subsection{Testing the Liquidity Hypothesis}

We designate subsamples of the database to directly test the liquidity hypothesis such that the subsamples are segmented on the basis of trading activity in the loan and equity markets. The 
two measures of loan market liquidity are the number of loan quotes and the loan bid/ask spread. The measure of equity market liquidity is the volume of equity transactions.

Table VI shows some support for the liquidity hypothesis. The most liquid loans tend to have more quotes and lower spreads. The information content of the loan market in explaining equity returns is analyzed in Table VI for the subsample with an above-median number of quotes in Column (2) and for the subsample with a below-median spread in Column (3); i.e., the most liquid loan portfolios. The significant (at the $10 \%$ level or better) coefficients for lagged and contemporaneous loan returns in explaining equity returns for the high number of quotes, Column (2), and low loan spreads, Column (3), subsamples suggests that loan returns have some explanatory power in determining equity returns when loan markets are relatively liquid. Moreover, equity returns have little explanatory power in determining loan returns when loan markets are relatively illiquid, as shown in Columns (1) and (4) in Table V. That is, when loan markets are illiquid (few quotes in Column (1) and high loan spreads in Column (4)), then lagged and contemporaneous equity returns have little or no explanatory power in determining loan returns. This provides support for the liquidity hypothesis in that information cannot be efficiently incorporated into prices in illiquid markets.

Controlling for equity market liquidity suggests further support for the liquidity hypothesis. The significant (at the 10\% level) coefficient on the lagged loan returns in Column (9) of Table VI is consistent with a leading information role for loan returns when equity markets are relatively illiquid. In contrast, when equity volume is high (Column (10) of Table VI), loan returns have no explanatory power in determining equity returns.

The Granger causality tests for the subsamples presented in Table VII provide further support for the liquidity hypothesis over the private information hypothesis. As we found in the 
Granger tests of whether lagged equity returns Granger cause loan returns presented in Table III, the Granger causality tests are all significant in Panel A, further supporting our conclusion that lagged equity returns Granger cause loan market returns. Significance is at the $1 \%$ level, with the exception of the subsample of loans without financial covenants, where the tests are significant at the $10 \%$ level.

We generally reject the hypothesis that lagged loan returns Granger cause equity returns, as indicated by the insignificance of almost all tests reported in Panel B of Table VII. However, when equity markets are relatively illiquid (i.e., when equity trading volume is low, as in Column (9) of Panel B of Table VII), then the Granger causality tests are significant at the 5\% level. These results suggest that lagged loan returns Granger cause equity returns when equity markets are illiquid. Further, when there are few loan market quotes the Granger causality tests are significant at the $10 \%$ level. Therefore, when the liquidity hypothesis does not hold because of market illiquidity, the private information inherent in loan prices becomes significant and the private information hypothesis is supported.

\section{Controlling for Borrower and Loan Characteristics}

In Sections 2 and 3, we use several methodologies to demonstrate that liquid equity markets lead bank loan markets, thereby supporting the liquidity hypothesis over the private information hypothesis. However, these results may be driven by specific loan or borrower characteristics. For example, the covenant structure of the bank loan dictates the private information flows that are made available to the lending syndicate, thereby impacting the informativeness of loan prices. Moreover, the structure of the syndicate itself (e.g., the number of 
lenders) will determine the efficiency with which information gained through bank monitoring is shared. In this section, we control for loan-specific and borrower-specific variables.

\subsection{Loan Facility-Specific and Borrower-Specific Data}

In this section, we describe additional loan facility-specific data and borrower-specific data as well as the methodology used to form equally-weighted portfolios of weekly loan and equity returns. Two types of variables are identified: those variables that vary across both time and across loan facilities, and loan facility variables that are recorded at the time of loan initiation, and do not vary across time for a specific loan facility.

The time-series variables include LNMV (the natural log of the market value of the borrowing firm's equity obtained from CRSP as of the date of the secondary loan market observation); LNDEBT (the natural logarithm of the borrower's debt obtained from COMPUSTAT for the year of the observation); LEVERAGE (the borrower's ratio of total debt to total assets obtained from COMPUSTAT for the year of the observation); INCOMTOA (the borrower's ratio of operating income before depreciation to total assets obtained from COMPUSTAT for the year of the observation); EPS (the borrower's earning per share obtained from COMPUSTAT for the year of the observation); and PENNYSTOCK (an indicator variable that takes on the value of 1 if the borrower's stock is priced below $\$ 1$ on the date of the secondary loan market observation). ${ }^{17}$

In addition, the time series variable PROB_KMV is the implied default probability on the date of the secondary market observation, estimated using the options-theoretic approach that is detailed in Allen and Peristiani (2004). ${ }^{18}$ Newton's nonlinear approximation technique is

\footnotetext{
${ }^{17}$ The stock price is standardized by the cumulative factor used by CRSP to adjust for splits and dividends.

${ }^{18}$ Also see Chapter 4 of Saunders and Allen (2002) for a general discussion of options-theoretic approaches.
} 
implemented to solve the following system of two nonlinear equations for borrower $i$ 's asset value and asset volatility at time $t, V_{A i t}$ and $\sigma_{A i t}$ :

$$
\begin{aligned}
V_{E i t} & =V_{A i t} N\left(D D_{i t}\right)-e^{-r_{i} T} L_{i t} N\left(D D_{i t}-\sigma_{A i t} \sqrt{T}\right) \\
\sigma_{E i t} & =\frac{V_{A i t}}{V_{E i t}} N\left(D D_{i t}\right) \sigma_{A i t}
\end{aligned}
$$

where $D D_{i t}=\left[\ln \left(V_{A i t} / L_{i t}\right)+T\left(r_{t}+0.5 \sigma^{2}{ }_{A i t}\right)\right] / \sigma_{A i t} \sqrt{T} \cdot V_{E i t}$ is the market value of borrower $i$ 's equity at time $t$ (defined earlier); $L_{i t}$ is the borrower's debt, defined as the value of the borrower's long-term debt as reported on COMPUSTAT for the fiscal year that ends in the same year as the secondary market observation; $r_{t}$ is the risk free rate, defined as the annualized one year constant maturity US Treasury bill rate from the Federal Reserve Bank of St. Louis on the date of the secondary market observation; $\sigma_{E i t}$ is borrower $i$ 's equity volatility at time $t$, defined as the standard deviation of the borrower's daily returns, extracted from CRSP, for a minimum of 30 and a maximum of 100 trading days before the date of the secondary market observation; $T$ is the one year estimation period, and $N($ ) is the normal distribution. Following the solution, we calculate the implied default probability as $N\left(-D D_{i t}\right)$.

Detailed data about the borrower and each loan facility as of the date of loan origination is available on Loan Pricing Corporation's Dealscan database. We use these data to obtain crosssectional control variables, which include measures of rating, loan size, spreads and fees, maturity, collateral, loan type, refinancing, covenants, lender participation, and purpose, all recorded at loan initiation. Debt rating is the Moody's senior debt rating. The borrower is nonrated for approximately $19 \%$ of the revolving and term loans initially extracted from the LPC database. In order to avoid eliminating a large proportion of observations due to the non-rated cases debt ratings, we create three indicator variables, designated ARATE, BRATE, and 
CRATE. ARATE is equal to unity if the debt rating is between A3 and Aaa and zero otherwise. Similarly, BRATE is equal to unity if the debt rating is between B3 and Baal and zero otherwise, while CRATE is equal to unity if the debt rating is between $\mathrm{C}$ and Caa and zero otherwise. Thus, the non-rated group, NOTRATED, is the base case.

Measures of loan size include LNDEALSIZE and LNFACILITYSIZE, which are the natural logarithm of the deal and facility size, respectively. Measures of spreads and fees include LSPREAD, UPFRONT_FEE, ANNUAL_FEE, and COMMITMENT_FEE. LSPREAD is the basis point coupon spread over LIBOR plus the annual fee and upfront fee, spread over the life of the loan, known as the "all in spread" in the LPC database. The UPFRONT_FEE variable is the upfront fee, the ANNUAL_FEE variable is the annual fee, and the COMMITMENT_FEE variable is the commitment fee charged on unused portions of the loan.

The bank loan's maturity, denoted MATURITY, is the number of days until the loan facility matures, as specified at initiation. The indicator variable SECURED_YES is equal to unity if the facility is designated as secured by collateral. Measures of loan type are LOAN_REVOLVER and LOAN_TERM, which are indicator variables that are equal to unity if the loan is a revolver or term loan, respectively. Thus, LOAN_OTHER is the base case. The measure of refinancing is REFINANCING_YES, which is an indicator variable that is equal to unity if LPC database designates the loan facility as stemming from a refinancing.

The existence of loan covenants is an important determinant of the information flows that are received by the lenders. For example, the borrower must supply the syndicate with detailed reports on a monthly basis to designate whether the loan covenants have been violated. If the loan covenants are financial in nature, then the borrower must reveal confidential information about the firm's financial condition. For example, the most commonly used loan covenant in our 
database specifies a maximum debt to EBITDA ratio. To demonstrate compliance with this covenant, the borrower must release monthly estimates of debt and earnings (EBITDA) to the loan syndicate. We define an indicator variable, FINANCIAL_COVENANT, to equal one if there the loan facility contains any of several financial covenants associated with the loan facility, including limitations on debt to EBITDA, debt to equity, net worth, tangible net worth, interest current ratios, and debt to tangible net worth ratios. The variable NONFINANCIAL_COVENANT is an indicator variable that is equal to unity if there are any of several nonfinancial covenants associated with the loan facility, including covenants related to dividend restrictions, term changes, asset sales sweep, insurance proceeds, equity issue sweep, and debt issue sweep. ${ }^{19}$ We define PPC to be an indicator variable that is equal to unity if the loan facility has a performance pricing covenant. ${ }^{20}$

The measure of lender participation is NUMBSYN, which is the number of lenders in the syndicate providing the loan. Esty and Megginson (2002) demonstrate that the structure of the syndicate (in particular, the number of syndicate members) can be used to offset deficiencies in the legal enforcement and shareholder rights environment. For example, in countries with weak shareholder rights and uncertain legal enforcement of claims, Esty and Megginson (2002) find that loan syndicates tend to be larger and more diffuse, thereby credibly precommiting the borrower to fulfillment of the loan's terms and precluding loan renegotiation.

We define variables related to the purpose of the syndicated bank loan. Allen and Peristiani (2004) show that general purpose bank loans are most subject to moral hazard and risk

\footnotetext{
${ }^{19}$ Sweeps require automatic prepayment of the bank loan with the proceeds of either asset sales (in an asset sales sweep covenant), equity or debt issues (in equity issue and debt issue sweeps, respectively). The form of this covenant is in percentage terms, designating the fraction of the proceeds that must be used to prepay the bank loan under the sweep trigger.

${ }^{20}$ The performance pricing covenant provides for automatic changes in the loan's spread triggered by changes in the firm's financial condition, as measured by loan ratings, financial ratios, etc.
} 
shifting and thus are priced differently than loans with proscribed goals. We define the following indicator variables: PURPOSE_CHANGE_OF_CONTROL (equal to unity if the purpose of the loan is as an acquisition line, IPO related, associated with a Leveraged Buyout or Management Buyout, spinoff related, or takeover related) and PURPOSE_ONGOING_BUSINESS (equal to unity if the purpose of the loan is for CP backup, capital expenditure, corporate purposes, debtor in possession, or working capital).

We identify the value of these time-series and cross sectional variables for every observation in the pooled sample described in Section 2.1, and eliminate all observations for which any variable is missing, resulting in a pooled sample size of 36,345 observations. We then form 194 equally-weighted weekly portfolios using this sample. Table VIII presents descriptive statistics for this sample. Note that the descriptive statistics reported for the measures used in the tests we perform in Sections 2 and 3 differ somewhat from the descriptive statistics presented in Table I. This is due to the elimination of all observations for which any variable is missing, which results in a somewhat different sample. In this sample, average weekly returns on equity, bank loans, the equity index and the loan index are all insignificantly different from zero, thereby removing the negative trend in returns shown in Table I.

\subsection{Cointegration Tests With Controls for Borrower- and Facility-Specific Characteristics}

In this section, we repeat the cointegration tests of the pooled sample detailed in Section 2, with the added refinement of controls for borrower- and facility-specific characteristics. Hence we add the time-varying and cross sectional variables specified in Section 4.1 as independent variables to the return-generating processes in equations (1) and (2), and estimate the relationship for both loan market returns, in equation (1), and equity market returns, in equation (2), using the Generalized Method of Moments. 
The results for the loan return generating function estimation of equation (1), presented in Table IX, indicate that the finding that equity markets lead loan markets in incorporating firmspecific information continues to hold in our controlled setting. The estimates of the coefficients of equation (1) shown in the first column of Table IX show a statistically significant (at the $1 \%$ level) coefficient on lagged equity returns $\left(R S_{t-1}\right)$ in explaining loan returns. This supports the result presented in Table II, suggesting that the inclusion of control variables does not change the conclusion that equity markets tend to lead bank loan markets.

However, the introduction of control variables provides some weak support for the explanatory power of loan returns in determining equity returns. The results of the estimation of equation (2), presented in Table IX for the $R S_{t}$ dependent variable, show that both lagged and contemporaneous loan returns have a statistically significant (at the 10\% level) impact on equity returns. This differs from our finding in Table II, in which these coefficients were statistically insignificant. Thus, not only do we find that equity returns have explanatory power in determining loan returns, we also find that loan returns have explanatory power with regard to equity returns, albeit at the $10 \%$ level.

The results for equation (1) also indicate a negative and statistically significant (at the 5\% level) coefficient associated with the contemporaneous market index, and a positive and statistically significant (at the $1 \%$ level) coefficient associated with the loan index. There is a positive statistically significant coefficient associated with LNMV, at the $10 \%$ level, and a negative statistically significant coefficient, at the $1 \%$ level, associated with ARATE. There is a positive and statistically significant coefficient associated with ANNUAL_FEE, significant at the $5 \%$ level. 
The results for equation (2) also indicate statistically significant positive coefficients, at the $5 \%$ level or better, for contemporaneous and lagged market returns. The coefficient associated with loan index is positive and significant at the $10 \%$ level, while the coefficient associated with the year variable is negative and significant at the $5 \%$ level. The coefficient associated with LNMV is positive and significant at the $1 \%$ level, while the coefficient associated with LNDEBT is negative and significant at the 5\% level. The coefficient associated with PENNYSTOCK is negative and significant at the $10 \%$ level, while the coefficient associated with CRATE is positive and significant at the $10 \%$ level. The coefficients associated with both LSPREAD and NUMBSYN are positive and significant at the $5 \%$ level.

\subsection{Direct Tests of the Liquidity and Private Information Hypotheses, With Controls for Borrower- and Facility-Specific Characteristics}

In this section, we directly test the liquidity and private information hypotheses for our sample with controls for borrower-and facility-specific characteristics. As we proceeded in Section 3.1, we use the sample median to divide our sample of 36,345 pooled observations into various subsamples in order to construct portfolios that differ systematically on the basis of liquidity and information content. These portfolios are then used to re-estimate equations (1) and (2) to test for integration between the loan and equity markets.

Table X reports the results of the GMM estimation of equation (1) for each subsample, testing whether lagged equity returns can explain loan returns. Column (7) of Table X reports the results for the more informationally intensive subsample of loans with financial covenants, as compared to Column (8) that shows the loans without financial covenants. Equity returns have significant (at the 10\% level or better) coefficients in both subsamples, a result inconsistent with 
the private information hypothesis. These results are consistent with our findings presented in Table V without borrower- and facility-specific controls.

Table XI presents the results of the GMM estimation of equation (2) testing whether lagged loan returns can explain equity returns for each subsample of the database. There is weak evidence in support of the private information hypothesis in that contemporaneous, but not lagged, loan returns have significant (at the $10 \%$ level only) explanatory power for informationally intensive loans with financial covenants (Column (7) of Table XI) and distressed loans (Column (5) of Table XI). However, if the private information hypothesis is accurate, we would anticipate that the lagged equity returns would not have any explanatory power in determining loan returns for the informationally intensive distressed subsample and for the loan covenants subsample. Columns (5) and (7) in Table X show that this is not the case, thereby refuting the private information hypothesis. As we found in Section 3.1, lagged equity returns have significant (at the 1\% level) coefficients in Column (5) of Table X for distressed loan portfolio returns, and in Column (7) for loan covenant portfolio returns, suggesting that equity markets lead loan markets in the most informationally intensive loan subsamples.

However, the controlled sample tests provide support for the private information hypothesis in the absence of liquidity, confirming the conclusions presented in Section 3 . That is, loan returns lead equity returns when equity volume is low, as shown by the statistically significant (at the $10 \%$ level or better) coefficients on lagged and contemporaneous loan returns in Column (9) of Table XI. Moreover, when loan markets are liquid (e.g., a high number of loan quotes), contemporaneous loan returns have a statistically significant (at the $1 \%$ level) coefficient in explaining equity returns. 
The results of the controlled estimation of equations (1) and (2) offer additional support for the liquidity hypothesis. For virtually all subsamples, equity returns lead loan returns, as shown in Columns (1), (2), (4), (5) (7), (8), (9) and (10) of Table X. The exception is for loan markets that are liquid; that is, loans with low spreads (Column (3) of Table X) and par loans (Column (6) of Table X). Controlling for equity market liquidity suggests further support for the liquidity hypothesis. The significant (at the 5\% level) coefficient on the lagged loan returns in Column (9) of Table XI is consistent with a leading information role for loan returns when equity markets are relatively illiquid. Thus, the results presented in Tables X and XI offer more support to the liquidity hypothesis than to the private information hypothesis.

Granger causality tests provide additional evidence consistent with the liquidity hypothesis. Table XII presents the results of Granger causality tests performed using equations (3) and (4), with addition of the control variables listed in Table VIII. As shown in Table VII, for the model without control variables, Panel A of Table XII shows that equity returns Granger cause loan returns for most subsegments. There are only two exceptions to this result. In Column (3) of Table XII Panel A, the Granger causality tests are insignificant for loan portfolios comprised of loans with low spreads. These are the most liquid loan markets. Thus, when loan markets are liquid, lagged equity returns are insignificant in determining returns on bank loans. Moreover, Column (9) of Table XII Panel A, shows a similar result for illiquid equity markets. That is, when equity market trading volume is low, equity markets are relatively information inefficient and thus, lagged equity returns have no impact on loan returns. These results offer further support for the liquidity hypothesis.

Panel B of Table XII offers support for the private information hypothesis in the absence of market liquidity. That is, Granger causality test results are insignificant for all subgroups, 
except the portfolios comprised of loans to borrowers with low volume equity market trading (Column (9) of Panel B). For this group, loan returns Granger cause equity returns. Thus, when equity markets are illiquid, the private information inherent in bank loans becomes significant (at the $5 \%$ level) in determining equity returns. Therefore, the controlled model results support the conclusions of Sections 2 and 3 - the private information hypothesis is only upheld in the absence of market liquidity.

\section{Conclusions}

To our knowledge, this is the first study to compare the informational efficiency of equity markets to syndicated bank loan secondary markets. We utilize three methodologies to conduct our tests: GMM cointegration tests of the return generating function for each market individually, Granger causality tests and estimation of abnormal returns on portfolios constructed using lagged market data.

We formulate two hypotheses. The private information hypothesis posits that loan markets lead equity markets because members of loan syndicates have access to superior, private information about borrowing firms. The liquidity hypothesis states that equity markets lead loan markets because loan markets are relatively illiquid as compared to public equity markets. Our results find support for the liquidity hypothesis. However, in the absence of liquidity (i.e., for relatively illiquid equity markets), we find support for the private information hypothesis. 


\section{References}

Allen, L., H. Guo and J. Weintrop, 2004, "The Information Content of Quarterly Earnings in Syndicated Bank Loan Prices," Baruch College Working Paper, August.

Allen, L. and S. Peristiani, 2004, "Conflicts of Interest in Merger Advisory Services," Baruch College Working Paper, May.

Altman, E., A. Gande, A. Saunders, 2003, "Informational Efficiency of Loans versus Bonds: Evidence from Secondary Market Prices," NYU Working Paper, April.

Blume, M.E., D.B. Keim and S.A. Patel, 1991, "Returns and Volatility of Low Grade Bonds: 1977-1989," Journal of Finance, 46 (1), March, pp. 49-74.

Boot, A.W.A. "Relationship Banking: What do we Know?", Journal of Financial Intermediation, 9 (1), 2000, pp. 7-25.

Bradley, M. and M.R. Roberts, 2004, "The Structure and Pricing of Corporate Debt Covenants," May 13, 2004, Duke University Working Paper.

Campbell, J., 1987, "Stock Returns and the Term Structure," Journal of Financial Economics, vol. 18, pp. 373-399.

Campbell, J. and J. Ammer, 1993, "What Moves the Stock and Bond Markets? A Variance Decomposition for Long-Term Asset Returns," Journal of Finance, vol. 48, pp. 3-37.

Cornell, B. and K. Green, 1991, "The Investment Performance of Low Grade Funds," Journal of Finance, vol. 46, pp. 29-48.

Dahiya, S., M. Puri, and A. Saunders, 2003, "Bank Borrowers and Loan Sales: New Evidence on the Uniqueness of Bank Loans," Journal of Business, vol. 76, no. 4, pp. 563-582.

Esty, B.C. and W.L. Megginson, 2002, "Creditor Rights Enforcement and Debt Ownership Structure: Evidence from the Global Syndicated Loan Market," Harvard Business School working paper.

Granger, C.W.J., 1969, "Investigating Causal Relations by Econometric Methods and Cross-Spectral Methods," Econometrica, 34, 424-438.

Hotchkiss, E.S. and T. Ronen, 2002, "The Informational Efficiency of the Corporate Bond Market: An Intraday Analysis," The Review of Financial Studies, Winter, vol. 15, no. 5, pp.1325-1354.

Keim, S. and R.F. Stambaugh, 1986, "Predicting Returns in the Stock and Bond Markets," Journal of Financial Economics, vol. 17, pp. 357-390. 
Kwan, S., 1996, "Firm Specific Information and the Correlation Between Individual Stocks and Bonds," Journal of Financial Economics, vol. 40, pp. 63-80.

Thomas, H. and Z. Wang, 2004, "The Integration of Bond Syndicated Loan and Junk Bond Markets," Journal of Banking and Finance, vol. 28, pp. 299-329.

Saunders, A. and L. Allen, 2002, Credit Risk Measurement: New Approaches to Value at Risk and Other Paradigms, second edition, New York: John Wiley and Sons.

Saunders, A., A. Srinivasan and I. Walter, 2002, "Price Formation in the OTC Corporate Bond Markets: A Field Study of the Inter-Dealer Market, Journal of Economics and Business, 54 (1), January/February, pp. 95-114.

Sims, C., 1972, "Money, Income and Causality," American Economic Review, 62, 540552. 
Table I. Descriptive statistics, return data. The mean, median, and standard deviation are reported for weekly portfolios consisting of equally weighted averages of all variables. Variable definitions are as follows: $R B_{t}$ is the weekly loan return. $R S_{t}$ is the weekly equity return. $R L_{t}$ is the weekly loan index return. $R M_{t}$ is the weekly equity index return. $R D_{t}$ is the weekly T-Bill return. $Y_{t}$ is the year of the observation. $N B A_{t}$ is sum of the number of bids and asks for the loan. $S P R D_{t}$ is the difference between average ask and average bid loan price, divided by the average of these two values. $V_{t}$ is the volume of trades on the equity market. ***, **, * denote t-test significance at the $1 \%, 5 \%$ and $10 \%$ levels, respectively.

\begin{tabular}{lcrr}
\hline Variable & Mean & Median & $\begin{array}{r}\text { Standard } \\
\text { Deviation }\end{array}$ \\
\hline$R B_{t}$ & $-0.0008^{* * *}$ & -0.0004 & 0.0030 \\
$R S_{t}$ & -0.0005 & -0.0037 & 0.0426 \\
$R L_{t}$ & -0.0001 & 0.0001 & 0.0030 \\
$R M_{t}$ & -0.0014 & -0.0018 & 0.0303 \\
$R D_{t}$ & $0.0010^{* * *}$ & 0.0011 & 0.0005 \\
$Y_{t}$ & $2000.8454^{* * *}$ & 2001.0000 & 1.2864 \\
$N B A_{t}$ & $8.0358^{* * *}$ & 8.1314 & 0.5782 \\
$S P R D_{t}$ & $0.0164^{* * *}$ & 0.0160 & 0.0028 \\
$V_{t}$ & $931,400.2427^{* * *}$ & $877,028.3537$ & $427,707.2133$ \\
\hline Sample Size & 194 & &
\end{tabular}


Table II. Cointegration Tests. We use the Generalized Method of Moments to estimate

$$
\begin{aligned}
& R B_{t}=\alpha_{t}+\beta_{1}^{B} R B_{t-1}+\sum_{i=0}^{2} \beta_{i}^{S} R S_{t-i}+\sum_{i=0}^{2} \beta_{i}^{M} R M_{t-i}+\beta_{0}^{L} R L_{t}+\beta_{0}^{D} R D_{t}+Y_{t}+N B A_{t}+S P R D_{t}+V_{t}+\varepsilon_{t} \\
& R S_{t}=\alpha_{t}+\sum_{i=0}^{1} \beta_{i}^{B} R B_{t-i}+\sum_{i=1}^{2} \beta_{i}^{S} R S_{t-i}+\sum_{i=0}^{2} \beta_{i}^{M} R M_{t-i}+\beta_{0}^{L} R L_{t}+\beta_{0}^{D} R D_{t}+Y_{t}+N B A_{t}+S P R D_{t}+V_{t}+\varepsilon_{t}
\end{aligned}
$$

for the sample of 194 weekly portfolios of equally weighted returns. Variable definitions are as follows: $R B_{t}$ is the loan return. $R S_{t}$ is the equity return. $R L_{t}$ is the loan index return. $R M_{t}$ is the equity index return. $R D_{t}$ is the T-Bill return. $Y_{t}$ is the year of the observation. $N B A_{t}$ is sum of the number of bids and asks for the loan. $S P R D_{t}$ is the difference between average ask and average bid, divided by the average of these two values. $V_{t}$ is the volume of trades on the equity market. $* * *, * * *$ denote significance at the $1 \%, 5 \%$ and $10 \%$ levels, respectively.

\begin{tabular}{lcc|cc}
\hline & \multicolumn{2}{c|}{ Eq. (1) $\left(R B_{t}\right.$ is dependent } & \multicolumn{2}{c}{ Eq. (2) $\left(R S_{t}\right.$ is dependent $)$} \\
\hline Variable & Coefficient & Standard Error & Coefficient & Standard Error \\
\hline Intercept & -0.0622 & 0.6393 & $-14.9279^{*}$ & 8.6444 \\
$R B_{t}$ & & & 1.4794 & 1.2443 \\
$R B_{t-1}$ & $0.418^{* * *}$ & 0.0935 & -0.6250 & 1.3938 \\
$R S_{t}$ & 0.0085 & 0.0068 & & \\
$R S_{t-1}$ & $0.0121^{* *}$ & 0.0059 & 0.1078 & 0.1092 \\
$R S_{t-2}$ & 0.0089 & 0.0056 & -0.0420 & 0.0813 \\
$R M_{t}$ & -0.0130 & 0.0085 & $1.0138^{* * *}$ & 0.0811 \\
$R M_{t-1}$ & 0.0036 & 0.0091 & 0.1369 & 0.1323 \\
$R M_{t-2}$ & -0.0081 & 0.0068 & 0.1615 & 0.1078 \\
$R L_{t}$ & $0.2738^{* * *}$ & 0.0712 & 1.2573 & 0.7811 \\
$R D_{t}$ & -0.4777 & 0.7485 & $21.4331^{*}$ & 11.5885 \\
$Y_{t}$ & 0.0000 & 0.0003 & $0.0074^{*}$ & 0.0043 \\
$N B A_{t}$ & 0.0001 & 0.0003 & -0.0007 & 0.0035 \\
$S P R D_{t}$ & -0.0492 & 0.0709 & -0.2512 & 0.8556 \\
$V_{t}$ & 0.0000 & 0.0000 & 0.0000 & 0.0000 \\
\hline Adjusted-R ${ }^{2}$ & 0.4959 & \multicolumn{3}{|c}{} \\
$N$ & 194 & & 0.5689 & \\
\hline
\end{tabular}


Table III. Bivariate Granger Causality Tests. We test causality between loan and equity return using OLS estimates of the following models:

$$
\begin{aligned}
& R B_{t}=\alpha_{t}+\beta_{1} R B_{t-1}+\beta_{2} R S_{t-1}+\varepsilon_{t}, \\
& R S_{t}=\alpha_{t}+\beta_{1} R S_{t-1}+\beta_{2} R B_{t-1}+\varepsilon_{t} .
\end{aligned}
$$

Each model is estimated twice: restricted, through excluding the variables $R S_{t-1}$ and $R B_{t-1}$ from equations (3) and (4), respectively, and unrestricted where these variables are not excluded. We then compare the sum of squared residuals for the unrestricted and restricted models, and conduct $F$-tests and asymptotically equivalent tests of the null hypothesis that $\beta_{2}=0$. Significance denotes a finding of Granger causality. Variable definitions are as follows: $R B_{t}$ is the loan return. $R S_{t}$ is the equity return. $* * *, * *, *$ denote significance at the $1 \%, 5 \%$ and $10 \%$ levels, respectively.

\begin{tabular}{lcc}
\hline & \multicolumn{1}{c}{$(1)$} & $(2)$ \\
\hline Variable & $\begin{array}{c}\text { Do equity returns Granger } \\
\text { cause loan returns? } \\
\text { Eq. (3) }\left(R B_{t} \text { is dependent) }\right.\end{array}$ & $\begin{array}{c}\text { Do loan returns Granger } \\
\text { cause equity returns? } \\
\text { Eq. (4) }\left(R S_{t} \text { is dependent) }\right.\end{array}$ \\
\hline Number of Observations & 194 & 194 \\
SSE restricted & 0.0011 & 0.3389 \\
SSE unrestricted & 0.0010 & 0.3369 \\
$F$-test & $29.5525^{* * *}$ & 1.1727 \\
Asymptotically equivalent test & $30.0167^{* * *}$ & 1.1911 \\
\hline
\end{tabular}


Table IV. Abnormal Returns on Long/Short Portfolios. For every week in the time period, we separately form equally weighted portfolios consisting of loan (equity) return observations for which the lag equity (loan) return in excess of the T-bill return is positive or negative. We then subtract the loan (equity) return on the negative lag equity (loan) portfolio from the return on the positive lag equity (loan) to simulate a portfolio consisting of long positions in loans (stocks) with positive lag equity (loan) returns and short positions in loans (stocks) with negative lag equity (loan) returns. We report the long/short portfolio returns in excess of the tbill return, the t-statistic for a test whether these excess portfolio returns are significantly different from zero, and the alpha associated with the following regression:

$$
R P_{t}=\alpha_{t}+\beta_{1} R I_{t}+\varepsilon_{t},
$$

where $R P_{t}$ is the return on the excess long/short loan (equity) portfolio and $R I_{t}$ is the return on the excess loan (equity) index portfolio. ${ }^{* *},{ }^{* *},{ }^{*}$ denote significance at the $1 \%, 5 \%$ and $10 \%$ levels, respectively.

\begin{tabular}{lll}
\hline \multicolumn{1}{c}{ Portfolio } & \multicolumn{1}{c}{ Mean } & Alpha \\
\hline Long/short loan portfolios formed using lag equity returns & $0.0006^{* *}$ & 0.0005 \\
Long/short equity portfolios formed using lag loan returns & 0.0040 & 0.0040 \\
\hline
\end{tabular}


Table V. Subsample Tests, Loan Return Dependent Variable. We use the Generalized Method of Moments to estimate:

$$
R B_{t}=\alpha_{t}+\beta_{1}^{B} R B_{t-1}+\sum_{i=0}^{2} \beta_{i}^{S} R S_{t-i}+\sum_{i=0}^{2} \beta_{i}^{M} R M_{t-i}+\beta_{0}^{L} R L_{t}+\beta_{0}^{D} R D_{t}+Y_{t}+N B A_{t}+S P R D_{t}+V_{t}+\varepsilon_{t},
$$

for 194 weekly portfolios of equally weighted returns, formed using the following subsamples of observations: Loan observations with quotes below (low loan quotes) or above (high loan quotes) the median; loan observations with loan quote spreads below (low loan spreads) or above (high loan spreads) the median; loans with price below $\$ 70$ (distressed loans) or above $\$ 90$ (par loans); loans and without financial covenants; and observations with equity volume below (low equity volume) or above (high equity volume) the median. Variable definitions are as follows: $R B_{t}$ is the loan return. $R S_{t}$ is the equity return. $R L_{t}$ is the loan index return. $R M_{t}$ is the equity index return. $R D_{t}$ is the T-Bill return. $Y_{t}$ is the year of the observation. $N B A_{t}$ is sum of the number of bids and asks for the loan. $S P R D_{t}$ is the difference between average ask and average bid, divided by the average of these two values. $V_{t}$ is the volume of trades on the equity market. ***,**,* denote significance at the $1 \%, 5 \%$ and $10 \%$ levels, respectively.

\begin{tabular}{|c|c|c|c|c|c|c|c|c|c|c|}
\hline Variable & $\begin{array}{c}\text { Low numbe } \\
\text { of loan } \\
\text { quotes } \\
\end{array}$ & $\begin{array}{c}\text { High number } \\
\text { of loan } \\
\text { quotes } \\
\end{array}$ & $\begin{array}{c}\text { Low loan } \\
\text { spreads } \\
\end{array}$ & $\begin{array}{c}\text { High loan } \\
\text { spreads }\end{array}$ & $\begin{array}{c}\text { Distressed } \\
\text { loans } \\
(\text { Price }<=70) \\
\end{array}$ & $\begin{array}{c}\text { Par loans } \\
(\text { Price }>=90)\end{array}$ & $\begin{array}{c}\text { Loans with } \\
\text { financial } \\
\text { covenants }\end{array}$ & $\begin{array}{c}\text { Loans without } \\
\text { financial } \\
\text { covenants }\end{array}$ & $\begin{array}{c}\text { Low equity } \\
\text { volume }\end{array}$ & $\begin{array}{c}\text { High equity } \\
\text { volume }\end{array}$ \\
\hline & (1) & (2) & (3) & (4) & $(5)$ & (6) & (7) & (8) & (9) & $(10)$ \\
\hline Intercept & -0.1596 & $1.7364 *$ & $0.2916^{* * *}$ & -0.1885 & -2.4428 & -0.1209 & 0.0606 & -0.5212 & 0.7569 & -0.7663 \\
\hline$R B_{t-1}$ & $0.4472 * * *$ & $0.2766 * *$ & $0.1742 *$ & $0.4131 * * *$ & 0.0909 & $0.3626^{* * *}$ & $0.3411 * * *$ & $0.2334 * *$ & $0.3692 * * *$ & $0.2675^{*}$ \\
\hline$R S_{t}$ & 0.0032 & $0.0141 *$ & $-0.002 * *$ & 0.0122 & 0.0146 & 0.0029 & $0.0132 *$ & -0.0040 & 0.0079 & 0.0084 \\
\hline$R S_{t-1}$ & 0.0106 & $0.017 * *$ & $0.0025 * *$ & $0.0140 * *$ & $0.0575^{* * *}$ & 0.0034 & $0.0109 *$ & 0.0015 & $0.0144 * * *$ & 0.0095 \\
\hline$R S_{t-2}$ & -0.0005 & $0.02 * * *$ & 0.0001 & $0.0119^{*}$ & 0.0217 & 0.0022 & $0.0144 * *$ & 0.0101 & $0.0083^{*}$ & $0.0141^{*}$ \\
\hline$R M_{t}$ & -0.006 & $-0.0222 * *$ & $0.0027 * *$ & $-0.0243^{*}$ & -0.1977 & -0.0028 & $-0.0204 * *$ & 0.0061 & -0.0050 & $-0.0227^{*}$ \\
\hline$R M_{t-1}$ & -0.0009 & 0.0026 & -0.0005 & 0.0125 & 0.0398 & 0.0007 & 0.0049 & 0.0071 & -0.0018 & 0.0093 \\
\hline$R M_{t-2}$ & 0.0050 & $-0.0245 * * *$ & -0.0001 & -0.0117 & -0.0243 & -0.0012 & $-0.0162 * *$ & 0.0103 & -0.0062 & -0.0108 \\
\hline$R L_{t}$ & $0.2437 * * *$ & $0.3086^{* * *}$ & $0.0227 * * *$ & $0.5012 * * *$ & 1.9100 & $0.0660 * * *$ & $0.2721 * * *$ & $0.3685^{* * *}$ & $0.2154 * * *$ & $0.3702 * * *$ \\
\hline$R D_{t}$ & 0.4855 & $-2.9095 * *$ & $-0.2641 * * *$ & -0.7912 & -7.2430 & -0.0997 & -0.7272 & -1.0819 & -0.8687 & -0.7274 \\
\hline$Y_{t}$ & 0.0001 & $-0.0009 *$ & $-0.0001 * * *$ & 0.0001 & 0.0012 & 0.0001 & 0.0000 & 0.0003 & -0.0004 & 0.0004 \\
\hline$N B A_{t}$ & -0.0024 & 0.0006 & $0.0001 * * *$ & -0.0001 & 0.0016 & 0.0000 & 0.0001 & 0.0000 & 0.0003 & -0.0002 \\
\hline$S P R D_{t}$ & 0.0657 & $-0.2134 * *$ & $0.2588 * *$ & -0.0638 & -0.0140 & 0.0525 & -0.0797 & -0.1035 & -0.0829 & $-0.1364 * *$ \\
\hline$V_{t}$ & 0.0000 & 0.0000 & 0.0000 & 0.0000 & 0.0000 & 0.0000 & 0.0000 & 0.0000 & 0.0000 & 0.0000 \\
\hline Adjusted-R ${ }^{2}$ & 0.377 & 0.4982 & 0.3306 & 0.4836 & 0.1054 & 0.3977 & 0.4520 & 0.1882 & 0.3582 & 0.3841 \\
\hline$N$ & 194 & 194 & 194 & 194 & 194 & 194 & 194 & 194 & 194 & 194 \\
\hline
\end{tabular}


Table VI. Subsample Tests, Equity Return Dependent Variable. We use the Generalized Method of Moments to estimate:

$$
R S_{t}=\alpha_{t}+\sum_{i=0}^{1} \beta_{i}^{B} R B_{t-i}+\sum_{i=1}^{2} \beta_{i}^{S} R S_{t-i}+\sum_{i=0}^{2} \beta_{i}^{M} R M_{t-i}+\beta_{0}^{L} R L_{t}+\beta_{0}^{D} R D_{t}+Y_{t}+N B A_{t}+S P R D_{t}+V_{t}+\varepsilon_{t} .
$$

for 194 weekly portfolios of equally weighted returns, formed using the following subsamples of observations: Loan observations with quotes below (low loan quotes) or above (high loan quotes) the median; loan observations with loan quote spreads below (low loan spreads) or above (high loan spreads) the median; loans with price below $\$ 70$ (distressed loans) or above $\$ 90$ (par loans); loans and without financial covenants; and observations with equity volume below (low equity volume) or above (high equity volume) the median. Variable definitions are as follows: $R B_{t}$ is the loan return. $R S_{t}$ is the equity return. $R L_{t}$ is the loan index return. $R M_{t}$ is the equity index return. $R D_{t}$ is the T-Bill return. $Y_{t}$ is the year of the observation. $N B A_{t}$ is sum of the number of bids and asks for the loan. $S P R D_{t}$ is the difference between average ask and average bid, divided by the average of these two values. $V_{t}$ is the volume of trades on the equity market. $* * *, * *, *$ denote significance at the $1 \%, 5 \%$ and $10 \%$ levels, respectively.

\begin{tabular}{|c|c|c|c|c|c|c|c|c|c|c|}
\hline Variable & $\begin{array}{c}\text { Low numbei } \\
\text { of loan } \\
\text { quotes } \\
\end{array}$ & $\begin{array}{c}\text { High number } \\
\text { of loan } \\
\text { quotes } \\
\end{array}$ & $\begin{array}{c}\text { Low loan } \\
\text { spreads } \\
\end{array}$ & $\begin{array}{c}\text { High loan } \\
\text { spreads }\end{array}$ & $\begin{array}{c}\text { Distressed } \\
\text { loans } \\
(\text { Price }<=70)\end{array}$ & $\begin{array}{c}\text { Par loans } \\
(\text { Price }>=90)\end{array}$ & $\begin{array}{c}\text { Loans with } \\
\text { financial } \\
\text { covenants }\end{array}$ & $\begin{array}{c}\text { Loans without } \\
\text { financial } \\
\text { covenants } \\
\end{array}$ & $\begin{array}{c}\text { Low equity } \\
\text { volume }\end{array}$ & $\begin{array}{c}\text { High equity } \\
\text { volume }\end{array}$ \\
\hline & (1) & (2) & (3) & (4) & $(5)$ & (6) & (7) & (8) & (9) & (10) \\
\hline Intercept & $-16.5090 * *$ & $-15.5341^{*}$ & $-9.4138 *$ & $-21.3647 *$ & -65.7609 & $-23.4039 * * *$ & $-17.2679 * *$ & -2.0686 & $-12.3284 * *$ & $-27.0682 * *$ \\
\hline$R B_{t}$ & 0.6070 & $1.4082 *$ & $-7.9265 * *$ & 1.5025 & 0.2423 & 2.7826 & 1.7795 & -0.4316 & 1.1464 & 1.0021 \\
\hline$R B_{t-1}$ & -1.3691 & 0.1804 & $6.6443 *$ & -0.9537 & -0.1615 & -1.7944 & -0.3138 & -0.0232 & $-2.7836^{*}$ & 0.9707 \\
\hline$R S_{t-1}$ & 0.0499 & 0.1017 & 0.0827 & 0.0928 & -0.0676 & 0.1041 & 0.1166 & 0.0103 & $0.1896^{* * *}$ & 0.0821 \\
\hline$R S_{t-2}$ & -0.0164 & -0.0509 & 0.0200 & -0.0588 & -0.0344 & 0.0289 & -0.0654 & -0.0572 & 0.0272 & -0.0578 \\
\hline$R M_{t}$ & $0.9804 * * *$ & $1.0389 * * *$ & $0.8116^{* * *}$ & $1.1877 * * *$ & $1.4107 * * *$ & $0.9445 * * *$ & $1.0236 * * *$ & $1.0461 * * *$ & $0.6806^{* * *}$ & $1.3167 * * *$ \\
\hline$R M_{t-1}$ & 0.1689 & 0.1903 & 0.0840 & 0.208 & 0.4927 & 0.0824 & 0.1247 & $0.2787 * *$ & -0.0172 & $0.2766^{*}$ \\
\hline$R M_{t-2}$ & 0.1113 & $0.2079 *$ & 0.0098 & $0.2869^{*}$ & 0.4698 & 0.0456 & $0.1902 *$ & $0.2282 * *$ & -0.0420 & $0.2761^{*}$ \\
\hline$R L_{t}$ & $1.9876^{* *}$ & 0.7753 & $1.2877 * * *$ & 1.4783 & 6.8840 & $1.3508 * *$ & 0.7183 & $3.6028 * *$ & 0.9199 & 0.8934 \\
\hline$R D_{t}$ & $18.9031^{*}$ & $18.2081 *$ & $12.0016^{*}$ & $31.3573 * *$ & 38.5570 & $23.0343 * *$ & $20.3589 * *$ & 17.6174 & 12.1305 & $31.7183^{*}$ \\
\hline$Y_{t}$ & $0.0083 * *$ & $0.0077^{*}$ & $0.0047^{*}$ & $0.0107^{*}$ & 0.0329 & $0.0117 * * *$ & $0.0086 * *$ & 0.0010 & $0.0062 * *$ & $0.0135 * *$ \\
\hline$N B A_{t}$ & -0.0178 & 0.0021 & 0.0014 & -0.0015 & -0.0043 & -0.0026 & -0.0028 & $0.0134 * *$ & -0.0025 & 0.0029 \\
\hline$S P R D_{t}$ & -0.4703 & 0.6218 & 8.2903 & -0.7287 & -0.1594 & 2.0288 & -0.6495 & 0.5801 & -0.2445 & 0.6794 \\
\hline$V_{t}$ & 0.0000 & 0.0000 & 0.0000 & 0.0000 & 0.0000 & 0.0000 & 0.0000 & $0.0000 * *$ & 0.0000 & 0.0000 \\
\hline Adjusted-R ${ }^{2}$ & 0.5428 & 0.5352 & 0.6883 & 0.4327 & 0.0463 & 0.6848 & 0.5760 & 0.3929 & 0.4323 & 0.5463 \\
\hline$N$ & 194 & 194 & 194 & 194 & 194 & 194 & 194 & 194 & 194 & 194 \\
\hline
\end{tabular}


Table VII. Bivariate Granger Causality Tests. We test causality between loan and equity return using OLS estimates of the following models:

$$
\begin{aligned}
& R B_{t}=\alpha_{t}+\beta_{1} R B_{t-1}+\beta_{2} R S_{t-1}+\varepsilon_{t}, \\
& R S_{t}=\alpha_{t}+\beta_{i} R S_{t-1}+\beta_{2} R B_{t-1}+\varepsilon_{t} .
\end{aligned}
$$

Each model is estimated twice: restricted, through excluding the variables $R S_{t-1}$ and $R B_{t-1}$ from equations (3) and (4), respectively, and unrestricted where these variables are not excluded. We then compare the sum of squared residuals for the unrestricted and restricted models, and conduct $F$-tests and asymptotically equivalent tests of the null hypothesis that $\beta_{2}=0$. Significance denotes a finding of Granger causality. Test results are reported for portfolios formed using the following subsamples of observations: Loan observations with quotes below (low loan quotes) or above (high loan quotes) the median; loan observations with loan quote spreads below (low loan spreads) or above (high loan spreads) the median; loans with price below $\$ 70$ (distressed loans) or above $\$ 90$ (par loans); loans and without financial covenants; and observations with equity volume below (low equity volume) or above (high equity volume) the median. Variable definitions are as follows: $R B_{t}$ is the loan return. $R S_{t}$ is the equity return. $* * *, * *, *$ denote significance at the $1 \%, 5 \%$ and $10 \%$ levels, respectively.

\begin{tabular}{|c|c|c|c|c|c|c|c|c|c|c|}
\hline Variable & $\begin{array}{c}\text { Low number } \\
\text { of loan } \\
\text { quotes } \\
\end{array}$ & $\begin{array}{l}\text { High number } \\
\text { of loan } \\
\text { quotes }\end{array}$ & $\begin{array}{c}\text { Low loan } \\
\text { spreads }\end{array}$ & $\begin{array}{c}\text { High loan } \\
\text { spreads }\end{array}$ & $\begin{array}{c}\text { Distressed } \\
\text { loans } \\
(\text { Price }<=70) \\
\end{array}$ & $\begin{array}{c}\text { Par loans } \\
(\text { Price }>=90)\end{array}$ & $\begin{array}{c}\text { Loans with } \\
\text { financial } \\
\text { covenants }\end{array}$ & $\begin{array}{c}\text { Loans without } \\
\text { financial } \\
\text { covenants }\end{array}$ & $\begin{array}{c}\text { Low equity } \\
\text { volume }\end{array}$ & $\begin{array}{c}\text { High equity } \\
\text { volume }\end{array}$ \\
\hline & $(1)$ & $(2)$ & (3) & (4) & $(5)$ & $(6)$ & (7) & $(8)$ & (9) & $(10)$ \\
\hline Number of Observations & 194 & 194 & 194 & 194 & 194 & 194 & 194 & 194 & 194 & 194 \\
\hline SSE restricted & 0.0010 & 0.0025 & 0.0000 & 0.0041 & 0.3875 & 0.0001 & 0.0014 & 0.0036 & 0.0011 & 0.0029 \\
\hline SSE unrestricted & 0.0009 & 0.0022 & 0.0000 & 0.0036 & 0.3601 & 0.0001 & 0.0013 & 0.0035 & 0.0010 & 0.0026 \\
\hline$F$-test & $17.2904 * * *$ & $27.5198 * * *$ & $7.6570 * * *$ & $27.2250 * * *$ & $14.5178 * * *$ & $17.7863 * * *$ & $25.3887 * * *$ & $3.2990^{*}$ & $18.2292 * * *$ & $19.9260 * * *$ \\
\hline Asymptotically equivalent test & $17.5620 * * *$ & $27.9520 * * *$ & $7.7773 * * *$ & $27.6526^{* * *}$ & $14.7459 * * *$ & $18.0657 * * *$ & $25.7875^{* * *}$ & $3.3508^{*}$ & $18.5156^{* * *}$ & $20.2390 * * *$ \\
\hline
\end{tabular}

Panel A. Loan Return Dependent Variable. . Significance denotes that lagged weekly equity returns Granger cause weekly loans returns.

\begin{tabular}{|c|c|c|c|c|c|c|c|c|c|c|}
\hline Variable & $\begin{array}{c}\text { Low number } \\
\text { of loan } \\
\text { quotes }\end{array}$ & $\begin{array}{c}\text { High number } \\
\text { of loan } \\
\text { quotes }\end{array}$ & $\begin{array}{c}\text { Low loan } \\
\text { spreads }\end{array}$ & $\begin{array}{c}\text { High loan } \\
\text { spreads }\end{array}$ & $\begin{array}{c}\text { Distressed } \\
\text { loans } \\
(\text { Price }<=70)\end{array}$ & $\begin{array}{c}\text { Par loans } \\
(\text { Price }>=90)\end{array}$ & $\begin{array}{c}\text { Loans with } \\
\text { financial } \\
\text { covenants }\end{array}$ & $\begin{array}{c}\text { Loans without } \\
\text { financial } \\
\text { covenants }\end{array}$ & $\begin{array}{c}\text { Low equity } \\
\text { volume }\end{array}$ & $\begin{array}{c}\text { High equity } \\
\text { volume }\end{array}$ \\
\hline & $(1)$ & $(2)$ & (3) & (4) & (5) & (6) & (7) & $(8)$ & $(9)$ & $(10)$ \\
\hline Number of Observations & 194 & 194 & 194 & 194 & 194 & 194 & 194 & 194 & 194 & 194 \\
\hline SSE restricted & 0.3486 & 0.3716 & 0.1694 & 0.6617 & 6.2635 & 0.2419 & 0.3301 & 0.5727 & 0.2175 & 0.5862 \\
\hline SSE unrestricted & 0.3431 & 0.3712 & 0.1690 & 0.6565 & 6.2478 & 0.2416 & 0.3289 & 0.5716 & 0.2108 & 0.5859 \\
\hline$F$-test & $3.0748^{*}$ & 0.2027 & 0.4046 & 1.5228 & 0.4814 & 0.2670 & 0.6889 & 0.3518 & $6.0980 * *$ & 0.1048 \\
\hline Asymptotically equivalent test & $3.1231 *$ & 0.2059 & 0.4110 & 1.5467 & 0.4890 & 0.2712 & 0.6998 & 0.3573 & $6.1938^{* *}$ & 0.1064 \\
\hline
\end{tabular}

Panel B. Equity Return Dependent Variable. Significance denotes that lagged weekly loan returns Granger cause weekly equity returns. 
Table VIII. Descriptive Statistics, Return, Facility-Specific, and Borrower-Specific Data. The mean, median, and standard deviation are reported for weekly portfolios consisting of equally weighted averages of all variables. Variables definitions are as follows: $R B_{t}$ is the loan return. $R S_{t}$ is the equity return. $R L_{t}$ is the loan index return. $R M_{t}$ is the equity index return. $R D_{t}$ is the T-Bill return. $Y_{t}$ is the year of the observation. $N B A_{t}$ is sum of the number of bids and asks for the loan. $S P R D_{t}$ is the difference between average ask and average bid, divided by the average of these two values. $V_{t}$ is the volume of trades on the equity market. PROB_KMV is the implied probability of default on the date of the observation. LNMV is the natural logarithm of the borrower's market value on the date of the observation. LNDEBT is the natural logarithm of the borrower's debt for the year of the observation. LEVERAGE is the borrower's ratio of total debt to total assets. INCOMTOA is the borrower's ratio of operating income before depreciation to total assets. EPS is the borrower's earning per share. PENNYSTOCK is an indicator variable that is equal to unity if the price of the borrower's stock is less than $\$ 1$ on the date of the observation. ARATE, BRATE, and CRATE are indicator variables that are equal to unity if the debt rating is between $\mathrm{A} 3$ and $\mathrm{Aaa}, \mathrm{B} 3$ and $\mathrm{Baa} 1$, and $\mathrm{C}$ and $\mathrm{Caa}$, respectively, and zero otherwise. LNDEALSIZE and LNFACILITYSIZE are the natural logarithm of the deal and facility size, respectively. LSPREAD is the basis point coupon spread over LIBOR plus the annual fee and upfront fee, spread over the life of the loan. UPFRONT_FEE is the upfront fee, ANNUAL_FEE is the annual fee, and COMMITMENT_FEE is the commitment fee charged on unused portions of the loan. MATURITY is the number of days until the loan facility matures, as specified at initiation. SECURED_YES is an indicator variable equal to unity if the facility is designated as securitized. LOAN_REVOLVER and LOAN_TERM are indicator variables that are equal to unity if the loan is a revolver or term loan, respectively. REFINANCING_YES is an indicator variable that is equal to unity if the loan facility is designated as being for refinancing. FINANCIAL_COVENANT is an indicator variable that is equal to unity if there are any of several financial covenants associated with the loan facility. NONFINANCIAL_COVENANT is an indicator variable that is equal to unity if there are any of several nonfinancial covenants associated with the loan facility. PPC is an indicator variable that is equal to unity if the loan facility has a performance pricing covenant. NUMBSYN is the number of lenders in the syndicate providing the loan. PURPOSE_CHANGE_OF_CONTROL is an indicator variable is an indicator variable that is equal to unity if the purpose of the loan is as an acquisition line, IPO related, associated with a Leveraged Buyout or Management Buyout, spinoff related, or takeover related. PURPOSE_ONGOING_BUSINESS is an indicator variable that is equal to unity if the purpose of the loan is for CP backup, capital expenditure, corporate purposes, debtor in possession, or working capital. ***,**,* denote t-test significance at the $1 \%, 5 \%$ and $10 \%$ levels, respectively. 


\begin{tabular}{|c|c|c|c|}
\hline Variable & Mean & Median & $\begin{array}{l}\text { Standard } \\
\text { Deviation }\end{array}$ \\
\hline$R B_{t}$ & -0.0001 & 0.0000 & 0.0024 \\
\hline$R S_{t}$ & 0.0024 & 0.0010 & 0.0388 \\
\hline$R L_{t}$ & -0.0001 & 0.0001 & 0.0030 \\
\hline$R M_{t}$ & -0.0014 & -0.0018 & 0.0303 \\
\hline$R D_{t}$ & $0.0010^{* * *}$ & 0.0011 & 0.0005 \\
\hline$Y_{t}$ & $2000.8454 * * *$ & 2001.0000 & 1.2864 \\
\hline$N B A_{t}$ & $8.1797 * * *$ & 8.2872 & 0.6826 \\
\hline$S P R D_{t}$ & $0.0140 * * *$ & 0.0131 & 0.0032 \\
\hline$V_{t}$ & $813,717.3311^{* * *}$ & $700,590.1215$ & $458,933.2086$ \\
\hline PROB_KMV & $0.0599 * * *$ & 0.0481 & 0.0335 \\
\hline LNMV & $20.4262 * * *$ & 20.4101 & 0.1867 \\
\hline LNDEBT & $20.6758 * * *$ & 20.6870 & 0.1429 \\
\hline LEVERAGE & $0.5856^{* * *}$ & 0.5566 & 0.0764 \\
\hline INCOMETOA & $0.1208 * * *$ & 0.1203 & 0.0054 \\
\hline EPS & $-1.4910 * * *$ & -0.8983 & 1.9041 \\
\hline PENNYSTOCK & $0.0266^{* * *}$ & 0.0189 & 0.0244 \\
\hline ARATE & $0.0067 * * *$ & 0.0049 & 0.0068 \\
\hline BRATE & $0.7066^{* * *}$ & 0.7336 & 0.0653 \\
\hline CRATE & $0.0974 * * *$ & 0.0987 & 0.0164 \\
\hline NOTRATED & $0.1843 * * *$ & 0.1441 & 0.0688 \\
\hline LNDEALSIZE & $20.5270 * * *$ & 20.5351 & 0.0613 \\
\hline LNFACILITYSIZE & $19.4042 * * *$ & 19.4099 & 0.0733 \\
\hline LSPREAD & $281.6256^{* * *}$ & 281.5558 & 4.3159 \\
\hline UPFRONT_FEE & $23.6248 * * *$ & 22.7834 & 3.1679 \\
\hline ANNUAL_FEE & $13.8602 * * *$ & 13.7677 & 1.2354 \\
\hline COMMITMENT_FEE & $5.0748 * * *$ & 5.1069 & 0.7238 \\
\hline MATURITY & $2,288.1402 * * *$ & $2,307.9445$ & 102.9828 \\
\hline SECURED_YES & $0.8833 * * *$ & 0.8810 & 0.0235 \\
\hline LOAN_REVOLVER & $0.1958 * * *$ & 0.2018 & 0.0263 \\
\hline LOAN_TERM & $0.7453 * * *$ & 0.7384 & 0.0269 \\
\hline LOAN_OTHER & $0.0588 * * *$ & 0.0578 & 0.0104 \\
\hline REFINANCING_YES & $0.6978 * * *$ & 0.7465 & 0.1371 \\
\hline FINANCIAL_COVENANT & $0.8613 * * *$ & 0.8631 & 0.0304 \\
\hline NONFINANCIAL_COVENANT & $0.9324 * * *$ & 0.9338 & 0.0249 \\
\hline PPC & $0.3620 * * *$ & 0.3523 & 0.1037 \\
\hline NUMBSYN & $17.1816^{* * *}$ & 17.3294 & 0.7316 \\
\hline PURPOSE_CHANGE_OF_CONTROL & $0.4975 * * *$ & 0.5110 & 0.0618 \\
\hline PURPOSE_ONGOING_BUSINESS & $0.1511^{* * *}$ & 0.1234 & 0.0620 \\
\hline Sample Size & 194 & & \\
\hline
\end{tabular}


Table IX. Cointegration Tests With Facility-Specific and Borrower-Specific Controls. We use the Generalized Method of Moments to repeat the cointegration tests reported in Tables II with loan facility-and borrower-specific control variables. Variable definitions are as follows: $R B_{t}$ is the loan return. $R S_{t}$ is the equity return. $R L_{t}$ is the loan index return. $R M_{t}$ is the equity index return. $R D_{t}$ is the T-Bill return. $Y_{t}$ is the year of the observation. $N B A_{t}$ is sum of the number of bids and asks for the loan. $S P R D_{t}$ is the difference between average ask and average bid, divided by the average of these two values. $V_{t}$ is the volume of trades on the equity market. PROB_KMV is the implied probability of default on the date of the observation. LNMV is the natural logarithm of the borrower's market value on the date of the observation. LNDEBT is the natural logarithm of the borrower's debt for the year of the observation. LEVERAGE is the borrower's ratio of total debt to total assets for the year of the observation. INCOMTOA is the borrower's ratio of operating income before depreciation to total assets for the year of the observation. EPS is the borrower's earning per share for the year of the observation. PENNYSTOCK is an indicator variable that is equal to unity if the price of the borrower's stock is less than $\$ 1$ on the date of the observation. ARATE, BRATE, and CRATE are indicator variables that are equal to unity if the debt rating is between $\mathrm{A} 3$ and $\mathrm{Aaa}, \mathrm{B} 3$ and $\mathrm{Baa}$, and $\mathrm{C}$ and Caa, respectively, and zero otherwise. LNDEALSIZE and LNFACILITYSIZE are the natural logarithm of the deal and facility size, respectively. LSPREAD is the basis point coupon spread over LIBOR plus the annual fee and upfront fee, spread over the life of the loan. UPFRONT_FEE is the upfront fee, ANNUAL_FEE is the annual fee, and COMMITMENT_FEE is the commitment fee charged on unused portions of the loan. MATURITY is the number of days until the loan facility matures, as specified at initiation. SECURED_YES is an indicator variable equal to unity if the facility is designated as securitized. LOAN REVOLVER and LOAN TERM are indicator variables that are equal to unity if the loan is a revolver or term loan, respectively. REFINANCING_YES is an indicator variable that is equal to unity if the loan facility is designated as being for refinancing. FINANCIAL_COVENANT is an indicator variable that is equal to unity if there are any of several financial covenants associated with the loan facility. NONFINANCIAL_COVENANT is an indicator variable that is equal to unity if there are any of several nonfinancial covenants associated with the loan facility. PPC is an indicator variable that is equal to unity if the loan facility has a performance pricing covenant. NUMBSYN is the number of lenders in the syndicate providing the loan. PURPOSE_CHANGE_OF_CONTROL is an indicator variable is an indicator variable that is equal to unity if the purpose of the loan is as an acquisition line, IPO related, associated with a Leveraged Buyout or Management Buyout, spinoff related, or takeover related. PURPOSE_ONGOING_BUSINESS is an indicator variable that is equal to unity if the purpose of the loan is for CP backup, capital expenditure, corporate purposes, debtor in possession, or working capital. $* * *, * * *$ denote significance at the $1 \%, 5 \%$ and $10 \%$ levels, respectively. 


\begin{tabular}{|c|c|c|c|c|}
\hline \multirow[b]{2}{*}{ Variable } & \multicolumn{2}{|c|}{$R B_{t}$ is dependent } & \multicolumn{2}{|c|}{$R S_{t}$ is dependent } \\
\hline & Coefficient & Standard Error & Coefficient & Standard Error \\
\hline Intercept & -0.0908 & 2.7910 & $80.3905 * *$ & 34.6727 \\
\hline$R B_{t}$ & & & $2.6744^{*}$ & 1.5355 \\
\hline$R B_{t-1}$ & $0.1859 *$ & 0.0972 & $-2.6319^{*}$ & 1.4616 \\
\hline$R S_{t}$ & $0.0127 *$ & 0.0071 & & \\
\hline$R S_{t-1}$ & $0.0144 * * *$ & 0.0053 & -0.0757 & 0.0893 \\
\hline$R S_{t-2}$ & 0.0036 & 0.0049 & -0.1074 & 0.0888 \\
\hline$R M_{t}$ & $-0.0183 * *$ & 0.0080 & $0.9093 * * *$ & 0.0752 \\
\hline$R M_{t-1}$ & -0.0082 & 0.0073 & $0.2193 * *$ & 0.1087 \\
\hline$R M_{t-2}$ & -0.0038 & 0.0058 & $0.2618 * *$ & 0.1124 \\
\hline$R L_{t}$ & $0.1584 * * *$ & 0.0495 & $1.0947 *$ & 0.6292 \\
\hline$R D_{t}$ & -2.7568 & 1.7018 & -14.9754 & 24.5479 \\
\hline$Y_{t}$ & -0.0001 & 0.0014 & $-0.0390 * *$ & 0.0173 \\
\hline$N B A_{t}$ & -0.0004 & 0.0005 & 0.0089 & 0.0075 \\
\hline$S P R D_{t}$ & -0.2161 & 0.1385 & -2.1825 & 1.9784 \\
\hline$V_{t}$ & 0.0000 & 0.0000 & 0.0000 & 0.0000 \\
\hline PROB_KMV & 0.0179 & 0.0137 & 0.2159 & 0.2322 \\
\hline LNMV & $0.0055^{*}$ & 0.0028 & $0.0991 * * *$ & 0.0351 \\
\hline LNDEBT & 0.0014 & 0.0050 & $-0.1393 * *$ & 0.0695 \\
\hline LEVERAGE & 0.0122 & 0.0228 & -0.3713 & 0.3052 \\
\hline INCOMETOA & -0.0446 & 0.0652 & -0.8149 & 0.9322 \\
\hline EPS & -0.0001 & 0.0002 & -0.0024 & 0.0023 \\
\hline PENNYSTOCK & -0.0028 & 0.0147 & $-0.3577^{*}$ & 0.1970 \\
\hline ARATE & $-0.2869 * * *$ & 0.1017 & 1.1517 & 1.3241 \\
\hline BRATE & -0.0131 & 0.0167 & 0.2657 & 0.2343 \\
\hline CRATE & 0.0054 & 0.0274 & $0.4869^{*}$ & 0.2546 \\
\hline LNDEALSIZE & -0.0109 & 0.0128 & 0.0464 & 0.1540 \\
\hline LNFACILITYSIZE & 0.0179 & 0.0139 & -0.1598 & 0.1686 \\
\hline LSPREAD & 0.0001 & 0.0001 & $0.0024 * *$ & 0.0010 \\
\hline UPFRONT_FEE & -0.0002 & 0.0002 & 0.004 & 0.0031 \\
\hline ANNUAL_FEE & $0.0008 * *$ & 0.0003 & -0.0062 & 0.0046 \\
\hline COMMITMENT_FEE & 0.0003 & 0.0005 & 0.0087 & 0.0070 \\
\hline MATURITY & 0.0000 & 0.0000 & 0.0001 & 0.0001 \\
\hline SECURED YES & 0.0251 & 0.0226 & -0.2806 & 0.2311 \\
\hline LOAN REV̄OLVER & 0.0151 & 0.0331 & -0.2025 & 0.3594 \\
\hline LOAN TERM & 0.0414 & 0.0458 & -0.4004 & 0.4152 \\
\hline REFINĀNCING YES & 0.0187 & 0.0132 & -0.2193 & 0.1815 \\
\hline FINANCIAL CŌVENANT & -0.0086 & 0.0210 & -0.0709 & 0.3049 \\
\hline NONFINANCIAL_COVENANT & 0.0176 & 0.0227 & 0.2656 & 0.3073 \\
\hline PPC & -0.0062 & 0.0151 & 0.2478 & 0.2141 \\
\hline NUMBSYN & -0.0006 & 0.0006 & $0.0145^{* *}$ & 0.0065 \\
\hline PURPOSE_CHANGE_OF_CONTROL & -0.0065 & 0.0168 & -0.1412 & 0.1962 \\
\hline PURPOSE_ONGOINḠ_BŪSINESS & -0.0194 & 0.0210 & 0.2919 & 0.2166 \\
\hline$\overline{\text { Adjusted-R }} \overline{2}$ & 0.5466 & & 0.6225 & \\
\hline$N$ & 194 & & 194 & \\
\hline
\end{tabular}


Table X. Subsample Tests, Loan Return Dependent Variable, With Facility-Specific and Borrower-Specific Controls. We use the Generalized Method of Moments to repeat the cointegration tests reported in Tables V with loan facility-and borrower-specific control variables. The portfolios of equally weighted returns are formed using the following subsamples of observations: Loan observations with quotes below (low loan quotes) or above (high loan quotes) the median; loan observations with loan quote spreads below (low loan spreads) or above (high loan spreads) the median; loans with price below $\$ 70$ (distressed loans) or above $\$ 90$ (par loans); loans and without financial covenants; and observations with equity volume below (low equity volume) or above (high equity volume) the median. Variable definitions are as follows: $R B_{t}$ is the loan return. $R S_{t}$ is the equity return. $R L_{t}$ is the loan index return. $R M_{t}$ is the equity index return. $R D_{t}$ is the T-Bill return. $Y_{t}$ is the year of the observation. $N B A_{t}$ is sum of the number of bids and asks for the loan. $S P R D_{t}$ is the difference between average ask and average bid, divided by the average of these two values. $V_{t}$ is the volume of trades on the equity market. PROB KMV is the implied probability of default on the date of the observation. LNMV is the natural logarithm of the borrower's market value on the date of the observation. LNDEBT is the natural logarithm of the borrower's debt for the year of the observation. LEVERAGE is the borrower's ratio of total debt to total assets for the year of the observation. INCOMTOA is the borrower's ratio of operating income before depreciation to total assets for the year of the observation. EPS is the borrower's earning per share for the year of the observation. PENNYSTOCK is an indicator variable that is equal to unity if the price of the borrower's stock is less than $\$ 1$ on the date of the observation. ARATE, BRATE, and CRATE are indicator variables that are equal to unity if the debt rating is between A3 and Aaa, B3 and Baal, and C and Caa, respectively, and zero otherwise. LNDEALSIZE and LNFACILITYSIZE are the natural logarithm of the deal and facility size, respectively. LSPREAD is the basis point coupon spread over LIBOR plus the annual fee and upfront fee, spread over the life of the loan. UPFRONT_FEE is the upfront fee, ANNUAL_FEE is the annual fee, and COMMITMENT FEE is the commitment fee charged on unused portions of the loan. MATURITY is the number of days until the loan facility matures, as specified at initiation. SECURED_YES is an indicator variable equal to unity if the facility is designated as securitized. LOAN_REVOLVER and LOAN TERM are indicator variables that are equal to unity if the loan is a revolver or term loan, respectively. REFINANCING YES is an indicator variable that is equal to unity if the loan facility is designated as being for refinancing. FINANCIAL_COVENANT is an indicator variable that is equal to unity if there are any of several financial covenants associated with the loan facility. NONFINANCIAL COVENANT is an indicator variable that is equal to unity if there are any of several nonfinancial covenants associated with the loan facility. PPC is an indicator variable that is equal to unity if the loan facility has a performance pricing covenant. NUMBSYN is the number of lenders in the syndicate providing the loan. PURPOSE_CHANGE_OF_CONTROL is an indicator variable is an indicator variable that is equal to unity if the purpose of the loan is as an acquisition line, IPO related, associated with a Leveraged Buyout or Management Buyout, spinoff related, or takeover related. PURPOSE_ONGOING_BUSINESS is an indicator variable that is equal to unity if the purpose of the loan is for CP backup, capital expenditure, corporate purposes, debtor in possession, or working capital. $* * *, * *,{ }^{*}$ denote significance at the $1 \%, 5 \%$ and $10 \%$ levels, respectively. 


\begin{tabular}{|c|c|c|c|c|c|c|c|c|c|c|}
\hline Variable & $\begin{array}{c}\text { Low number } \\
\text { of loan } \\
\text { quotes }\end{array}$ & $\begin{array}{c}\text { High number } \\
\text { of loan } \\
\text { quotes }\end{array}$ & $\begin{array}{c}\text { Low loan } \\
\text { spreads }\end{array}$ & $\begin{array}{c}\text { High loan } \\
\text { spreads }\end{array}$ & $\begin{array}{c}\text { Distressed } \\
\text { loans } \\
(\text { Price }<=70)\end{array}$ & $\begin{array}{c}\text { Par loans } \\
(\text { Price }>=90)\end{array}$ & $\begin{array}{l}\text { Loans with } \\
\text { financial } \\
\text { covenants }\end{array}$ & $\begin{array}{c}\text { Loans without } \\
\text { financial } \\
\text { covenants }\end{array}$ & $\begin{array}{c}\text { Low equity } \\
\text { volume }\end{array}$ & $\begin{array}{c}\text { High equity } \\
\text { volume }\end{array}$ \\
\hline & (1) & $(2)$ & (3) & (4) & (5) & (6) & (7) & $(8)$ & (9) & $(10)$ \\
\hline Intercept & $4.1653^{* *}$ & 0.2547 & 0.0227 & 2.4512 & -82.4894 & 0.4026 & -1.0747 & 0.3935 & $3.0284 *$ & 0.8421 \\
\hline$R B_{t-1}$ & $0.2929 * * *$ & 0.1292 & 0.0015 & $0.2419 * * *$ & -0.0003 & 0.1015 & 0.0997 & 0.1011 & $0.1799^{*}$ & $0.3307 * * *$ \\
\hline$R S_{t}$ & 0.0117 & $0.0234 * * *$ & -0.0017 & 0.0133 & $0.0659 * * *$ & 0.002 & $0.015^{* *}$ & 0.0014 & $0.0144 *$ & $0.0205 * * *$ \\
\hline$R S_{t-1}$ & $0.014 *$ & $0.0214 * * *$ & 0.0009 & $0.0175 * * *$ & $0.0766^{* * *}$ & 0.0022 & $0.0148 * * *$ & $0.0144 *$ & 0.0058 & $0.0108 * *$ \\
\hline$R S_{t-2}$ & -0.0013 & 0.0086 & 0.0012 & 0.0021 & 0.0219 & 0.0024 & 0.007 & $0.0254 * *$ & 0.0045 & 0.0044 \\
\hline$R M_{t}$ & $-0.0207 * *$ & $-0.0242 * * *$ & 0.0018 & $-0.0236^{* *}$ & $-0.303 * *$ & -0.0038 & $-0.0239 * * *$ & -0.004 & -0.0077 & $-0.0357 * * *$ \\
\hline$R M_{t-1}$ & $-0.0155^{*}$ & $-0.0137 *$ & -0.0001 & -0.0109 & -0.0954 & 0.0008 & -0.0074 & -0.0101 & 0.0004 & -0.0008 \\
\hline$R M_{t-2}$ & -0.0029 & $-0.0128^{*}$ & -0.001 & -0.0026 & 0.0915 & -0.0019 & -0.0074 & -0.0007 & -0.0039 & -0.0052 \\
\hline$R L_{t}$ & $0.1382 * *$ & $0.2181 * * *$ & 0.0106 & $0.2645 * * *$ & 1.0054 & $0.0573 * * *$ & $0.1536 * * *$ & $0.2179^{*}$ & $0.182 * * *$ & $0.203 * * *$ \\
\hline$R D_{t}$ & -1.2349 & -2.7116 & -0.1283 & -0.389 & 33.2694 & $-1.8841 * *$ & -3.8519 & 4.382 & -1.029 & -0.4171 \\
\hline$Y_{t}$ & $-0.002 * *$ & -0.0001 & 0.0000 & -0.0012 & 0.0416 & -0.0002 & 0.0005 & -0.0004 & $-0.0015 *$ & -0.0004 \\
\hline$N B A_{t}$ & $-0.0071 *$ & 0.0001 & 0.0000 & -0.0011 & 0.0037 & 0.0001 & -0.0002 & -0.0014 & -0.0002 & 0.0003 \\
\hline$S P R D_{t}$ & 0.0812 & $-0.6678 * * *$ & $0.4033^{*}$ & $-0.2932^{* *}$ & $-0.3998 * *$ & -0.013 & $-0.3725^{* *}$ & $-0.3606^{*}$ & $-0.3783 * * *$ & $0.1485^{*}$ \\
\hline$V_{t}$ & 0.0000 & 0.0000 & 0.0000 & 0.0000 & $0.0000^{*}$ & 0.0000 & 0.0000 & 0.0000 & 0.0000 & 0.0000 \\
\hline PROB KMV & 0.0029 & $0.0575 * * *$ & 0.0008 & 0.013 & -0.1299 & -0.0136 & $0.0346 * *$ & 0.0538 & 0.0099 & 0.0063 \\
\hline LNMV & $0.0043^{*}$ & 0.0019 & -0.0004 & $0.0059^{*}$ & -0.03 & 0.0016 & $0.0068 * * *$ & 0.0003 & 0.0018 & -0.0004 \\
\hline LNDEBT & 0.0025 & -0.007 & 0.0000 & 0.0059 & 0.0113 & 0.0022 & -0.0081 & $0.0081 *$ & 0.0006 & 0.0037 \\
\hline LEVERAGE & -0.0026 & 0.0158 & -0.0014 & $0.0333^{*}$ & -0.0804 & 0.0085 & $0.0423 *$ & 0.0134 & 0.0035 & -0.0016 \\
\hline INCOMETOA & 0.0568 & $-0.1175 * *$ & -0.0004 & -0.1114 & $-0.6252 *$ & 0.022 & -0.1009 & 0.0608 & 0.0381 & $-0.0399 *$ \\
\hline EPS & $-0.0002 *$ & 0.0004 & -0.0001 & -0.0001 & 0.0001 & -0.0001 & 0.0009 & $-0.0002 * *$ & -0.0002 & 0.0000 \\
\hline PENNYSTOCK & 0.0176 & 0.0055 & 0.0001 & 0.0000 & 0.0321 & 0.0014 & -0.0063 & 0.0159 & -0.0007 & $-0.0162 *$ \\
\hline ARATE & $-0.0952 * *$ & -0.0304 & -0.0039 & -0.0352 & 0.0001 & $-0.0527 *$ & $-0.3255^{* * *}$ & 0.0001 & 0.0198 & -0.0448 \\
\hline BRATE & -0.0081 & $-0.0366^{* *}$ & -0.0008 & 0.0111 & 0.0705 & -0.0036 & -0.0032 & -0.0019 & 0.0024 & -0.0068 \\
\hline CRATE & 0.0002 & 0.0105 & 0.0044 & -0.0402 & -0.131 & 0.0095 & 0.0338 & 0.0059 & 0.0121 & $-0.0288 * *$ \\
\hline LNDEALSIZE & -0.0102 & 0.0075 & $0.0019 * *$ & $-0.0237 *$ & 0.0689 & -0.0072 & -0.0094 & 0.0055 & $-0.014 * * *$ & -0.0001 \\
\hline LNFACILITYSIZE & -0.0017 & -0.0063 & 0.0000 & 0.0089 & -0.0684 & 0.0048 & 0.0214 & 0.0009 & $0.0123^{* * *}$ & -0.006 \\
\hline LSPREAD & 0.0000 & -0.0001 & $0.0000 * *$ & 0.0001 & -0.0001 & 0.0000 & 0.0002 & 0.0000 & $0.0001 * *$ & 0.0000 \\
\hline UPFRONT_FEE & 0.0000 & -0.0001 & $0.0000 * *$ & 0.0000 & 0.0014 & 0.0000 & -0.0003 & 0.0000 & 0.0001 & $0.0001 *$ \\
\hline ANNUAL_FEE & 0.0001 & 0.0001 & $0.0000 * * *$ & 0.0001 & -0.0005 & 0.0001 & $0.0008 * * *$ & 0.0000 & 0.0000 & $0.0001 *$ \\
\hline COMMITMENT_FEE & $-0.0007 * *$ & -0.0001 & 0.0000 & 0.0006 & -0.0023 & 0.0001 & -0.0003 & 0.0002 & 0.0000 & -0.0001 \\
\hline MATURITY & 0.0000 & 0.0000 & 0.0000 & 0.0000 & -0.0001 & 0.0000 & $0.0000^{*}$ & 0.0000 & 0.0000 & 0.0000 \\
\hline SECURED YES & $0.0276^{*}$ & 0.0081 & $0.0067 * * *$ & 0.0056 & -0.0762 & 0.0074 & 0.0128 & -0.0179 & -0.0059 & -0.0086 \\
\hline LOAN_REVOLVER & 0.0164 & 0.0312 & $0.0059^{*}$ & -0.0472 & 0.0514 & -0.0109 & $0.0751 * *$ & 0.0104 & -0.0097 & $0.0529 * * *$ \\
\hline LOAN_TERM & 0.0085 & 0.0249 & $0.0058^{* *}$ & -0.0395 & 0.1559 & -0.0057 & $0.0767 * *$ & 0.0289 & -0.003 & $0.0512 * * *$ \\
\hline REFINĀANCING_YES & 0.0061 & 0.0086 & -0.0007 & -0.0092 & -0.1551 & 0.003 & 0.018 & 0.015 & $0.0111^{*}$ & 0.0033 \\
\hline FINANCIAL_CŌVENANT & 0.0078 & 0.018 & -0.0022 & -0.0191 & 0.0262 & 0.0107 & 0.0001 & 0.0001 & 0.0026 & -0.011 \\
\hline NONFINANCIAL_COVENANT & -0.0084 & 0.0005 & $0.0054 * *$ & 0.0038 & -0.0511 & -0.0073 & -0.1189 & $-0.0202 *$ & 0.0006 & 0.0126 \\
\hline PPC & -0.0067 & $-0.0357 * * *$ & -0.0004 & 0.0083 & -0.157 & -0.0007 & -0.0026 & -0.0075 & 0.0014 & $-0.0138 * * *$ \\
\hline NUMBSYN & -0.0002 & -0.0002 & 0.0000 & 0.0003 & 0.0037 & 0.0001 & -0.001 & -0.0001 & 0.0001 & -0.0002 \\
\hline PURPOSE_CHANGE_OF_CONTROL & 0.0063 & 0.0008 & -0.0004 & -0.0051 & -0.054 & -0.0014 & 0.0117 & -0.0042 & 0.0038 & -0.006 \\
\hline PURPOSE ONGOING BÜSINESS & 0.0121 & 0.0059 & 0.003 & -0.0207 & -0.0548 & 0.0028 & -0.014 & 0.0125 & $-0.0153 * *$ & 0.0021 \\
\hline$\overline{\text { Adjusted-R }}{ }^{2}$ & 0.4699 & 0.5679 & 0.3827 & 0.5581 & 0.3106 & 0.3548 & 0.4871 & 0.3512 & 0.3012 & 0.5789 \\
\hline$N$ & 194 & 194 & 194 & 194 & 167 & 194 & 194 & 194 & 194 & 194 \\
\hline
\end{tabular}


Table XI. Subsample Tests, Equity Return Dependent Variable, With Facility-Specific and Borrower-Specific Controls. We use the Generalized Method of Moments to repeat the cointegration tests reported in Tables VI with loan facility-and borrower-specific control variables. The portfolios of equally weighted returns are formed using the following subsamples of observations: Loan observations with quotes below (low loan quotes) or above (high loan quotes) the median; loan observations with loan quote spreads below (low loan spreads) or above (high loan spreads) the median; loans with price below $\$ 70$ (distressed loans) or above $\$ 90$ (par loans); loans and without financial covenants; and observations with equity volume below (low equity volume) or above (high equity volume) the median. Variable definitions are as follows: $R B_{t}$ is the loan return. $R S_{t}$ is the equity return. $R L_{t}$ is the loan index return. $R M_{t}$ is the equity index return. $R D_{t}$ is the T-Bill return. $Y_{t}$ is the year of the observation. $N B A_{t}$ is sum of the number of bids and asks for the loan. $S P R D_{t}$ is the difference between average ask and average bid, divided by the average of these two values. $V_{t}$ is the volume of trades on the equity market. PROB KMV is the implied probability of default on the date of the observation. LNMV is the natural logarithm of the borrower's market value on the date of the observation. LNDEBT is the natural logarithm of the borrower's debt for the year of the observation. LEVERAGE is the borrower's ratio of total debt to total assets for the year of the observation. INCOMTOA is the borrower's ratio of operating income before depreciation to total assets for the year of the observation. EPS is the borrower's earning per share for the year of the observation. PENNYSTOCK is an indicator variable that is equal to unity if the price of the borrower's stock is less than $\$ 1$ on the date of the observation. ARATE, BRATE, and CRATE are indicator variables that are equal to unity if the debt rating is between A3 and Aaa, B3 and Baa1, and C and Caa, respectively, and zero otherwise. LNDEALSIZE and LNFACILITYSIZE are the natural logarithm of the deal and facility size, respectively. LSPREAD is the basis point coupon spread over LIBOR plus the annual fee and upfront fee, spread over the life of the loan. UPFRONT_FEE is the upfront fee, ANNUAL_FEE is the annual fee, and COMMITMENT FEE is the commitment fee charged on unused portions of the loan. MATURITY is the number of days until the loan facility matures, as specified at initiation. SECURED_YES is an indicator variable equal to unity if the facility is designated as securitized. LOAN_REVOLVER and LOAN TERM are indicator variables that are equal to unity if the loan is a revolver or term loan, respectively. REFINANCING YES is an indicator variable that is equal to unity if the loan facility is designated as being for refinancing. FINANCIAL_COVENANT is an indicator variable that is equal to unity if there are any of several financial covenants associated with the loan facility. NONFINANCIAL COVENANT is an indicator variable that is equal to unity if there are any of several nonfinancial covenants associated with the loan facility. PPC is an indicator variable that is equal to unity if the loan facility has a performance pricing covenant. NUMBSYN is the number of lenders in the syndicate providing the loan. PURPOSE_CHANGE_OF_CONTROL is an indicator variable is an indicator variable that is equal to unity if the purpose of the loan is as an acquisition line, IPO related, associated with a Leveraged Buyout or Management Buyout, spinoff related, or takeover related. PURPOSE_ONGOING_BUSINESS is an indicator variable that is equal to unity if the purpose of the loan is for CP backup, capital expenditure, corporate purposes, debtor in possession, or working capital. $* * *, * *,{ }^{*}$ denote significance at the $1 \%, 5 \%$ and $10 \%$ levels, respectively. 


\begin{tabular}{|c|c|c|c|c|c|c|c|c|c|c|}
\hline Variable & $\begin{array}{c}\text { Low number } \\
\text { of loan } \\
\text { quotes }\end{array}$ & $\begin{array}{c}\text { High number } \\
\begin{array}{c}\text { of loan } \\
\text { quotes }\end{array}\end{array}$ & $\begin{array}{c}\text { Low loan } \\
\text { spreads }\end{array}$ & $\begin{array}{c}\text { High loan } \\
\text { spreads }\end{array}$ & $\begin{array}{c}\text { Distressed } \\
\text { loans } \\
(\text { Price }<=70) \\
\end{array}$ & $\begin{array}{c}\text { Par loans } \\
(\text { Price }>=90)\end{array}$ & $\begin{array}{l}\text { Loans with } \\
\text { financial } \\
\text { covenants }\end{array}$ & $\begin{array}{c}\text { Loans without } \\
\text { financial } \\
\text { covenants }\end{array}$ & $\begin{array}{c}\text { Low equity } \\
\text { volume }\end{array}$ & $\begin{array}{c}\text { High equity } \\
\text { volume }\end{array}$ \\
\hline & (1) & (2) & (3) & (4) & $(5)$ & $(6)$ & $(7)$ & $(8)$ & $(9)$ & $(10)$ \\
\hline Intercept & 29.7408 & 0.2198 & 16.4446 & 2.3385 & 340.8145 & 13.216 & 12.218 & 66.9423 & 9.3042 & -5.7 \\
\hline$R B_{t}$ & 2.2896 & $4.0302 * * *$ & -7.3384 & 2.127 & $1.4151^{*}$ & 1.4381 & $2.7011^{*}$ & 0.0995 & $1.5918^{*}$ & $4.168 * * *$ \\
\hline$R B_{t-1}$ & -1.3061 & -1.0706 & 4.4776 & $-3.1904 * * *$ & 0.1231 & -2.6325 & -2.1311 & 0.5055 & $-2.1072 * *$ & -0.3374 \\
\hline$R S_{t-1}$ & $-0.1611 * *$ & $-0.1556^{*}$ & -0.0311 & -0.0587 & $-0.455 * * *$ & -0.0677 & -0.0526 & $-0.2475^{* *}$ & 0.0248 & -0.0969 \\
\hline$R S_{t-2}$ & -0.1401 & $-0.2189 * *$ & -0.0597 & -0.1112 & -0.2051 & -0.0068 & -0.1355 & $-0.1985 * *$ & -0.0552 & $-0.222 * *$ \\
\hline$R M_{t}$ & $0.9436^{* * *}$ & $0.8941^{* * *}$ & $0.7753 * * *$ & $1.0564 * * *$ & $1.554 * * *$ & $0.8289 * * *$ & $0.9444 * * *$ & $0.8046 * * *$ & $0.684 * * *$ & $1.1602 * * *$ \\
\hline$R M_{t-1}$ & $0.2866 * * *$ & $0.257 * *$ & $0.1528 *$ & 0.1831 & $1.7006^{* * *}$ & $0.1954 * *$ & 0.178 & $0.4718^{* * *}$ & 0.1044 & $0.2757 * *$ \\
\hline$R M_{t-2}$ & $0.3159 * * *$ & $0.3122 * * *$ & 0.0873 & $0.3536^{* *}$ & 0.4273 & 0.1064 & $0.2731 * *$ & $0.4283 * * *$ & 0.018 & $0.4099 * * *$ \\
\hline$R L_{t}$ & $1.6528 * *$ & 0.5387 & $0.9513 *$ & 1.3859 & $8.6644 * *$ & 0.722 & 0.9911 & $3.0885^{* *}$ & 0.5426 & 0.9962 \\
\hline$R D_{t}$ & 16.511 & -7.7891 & 20.6771 & 53.4549 & -155.0991 & -1.0186 & 26.8293 & 23.2015 & 5.6816 & 15.3966 \\
\hline$Y_{t}$ & -0.0148 & -0.0005 & -0.0087 & -0.001 & -0.1747 & -0.0062 & -0.0059 & -0.0328 & -0.0043 & 0.0038 \\
\hline$N B A_{t}$ & 0.0439 & 0.0008 & $0.0074 * * *$ & -0.0087 & $0.0545^{*}$ & 0.0024 & 0.0021 & 0.0083 & 0.005 & $0.0078 * *$ \\
\hline$S P R D_{t}$ & -1.0427 & $8.5965^{* * *}$ & $28.3777 * *$ & -1.1137 & -0.7081 & 4.2082 & 0.3565 & 0.7812 & 0.785 & -0.5324 \\
\hline$V_{t}$ & 0.0000 & 0.0000 & $0.0000 * * *$ & 0.0000 & 0.0000 & 0.0000 & 0.0000 & 0.0000 & 0.0000 & 0.0000 \\
\hline PROB_KMV & 0.1100 & -0.1683 & $-1.0196^{* *}$ & $0.3975^{* *}$ & $1.325 * *$ & -0.3802 & -0.1229 & 0.4743 & -0.158 & -0.0061 \\
\hline LNMV & 0.0466 & $0.1024 * * *$ & $0.0654 * * *$ & $0.086^{* *}$ & $0.4823 * * *$ & $0.1345^{* * *}$ & $0.0774 * *$ & $0.1414 * * *$ & -0.0002 & $0.0378^{*}$ \\
\hline LNDEBT & $-0.0783^{* *}$ & 0.049 & -0.0377 & -0.0314 & -0.0467 & $-0.088 *$ & -0.0581 & $-0.0862 * *$ & 0.0038 & $-0.0535^{*}$ \\
\hline LEVERAGE & -0.1356 & -0.1714 & 0.0933 & 0.1585 & 0.5951 & -0.0005 & -0.0149 & $0.3108^{*}$ & -0.0254 & $0.249 * *$ \\
\hline INCOMETOA & -0.8565 & -0.1666 & 0.2063 & 0.132 & $4.4498 * * *$ & -0.7589 & $-1.8371 *$ & $0.706^{* *}$ & 0.0024 & 0.4468 \\
\hline EPS & -0.0003 & -0.0052 & 0.0001 & $0.0036^{* *}$ & -0.0009 & -0.0041 & -0.0012 & -0.0002 & 0.0006 & 0.0014 \\
\hline PENNYSTOCK & -0.1454 & -0.2375 & 0.0001 & -0.0942 & -0.0508 & 0.137 & -0.1525 & $-0.3197 * * *$ & $-0.1962 *$ & 0.0933 \\
\hline ARATE & 1.1634 & $-1.7448 *$ & -0.3253 & 0.9865 & 0.0001 & 0.5781 & 1.3259 & 0.0001 & 0.2582 & -0.1009 \\
\hline BRATE & $0.3338 * * *$ & -0.0126 & 0.0018 & 0.2879 & -0.7167 & $0.3204 *$ & 0.0255 & $0.3679 * * *$ & 0.0354 & $0.2109 * * *$ \\
\hline CRATE & $0.4145^{* *}$ & -0.1858 & $0.3105^{*}$ & -0.1489 & $1.211^{* *}$ & $0.8293 * * *$ & 0.5467 & 0.2243 & 0.0324 & $0.3661 * *$ \\
\hline LNDEALSIZE & -0.1081 & 0.0056 & $-0.1281 * *$ & -0.112 & -0.106 & -0.0975 & -0.1426 & -0.093 & -0.0694 & -0.0246 \\
\hline LNFACILITYSIZE & 0.1162 & -0.1463 & $0.1313 * *$ & 0.0201 & 0.1067 & -0.0259 & -0.0238 & -0.0513 & 0.0432 & -0.0691 \\
\hline LSPREAD & 0.0003 & 0.0001 & 0.0003 & 0.0001 & -0.0006 & 0.0011 & -0.0004 & 0.0005 & -0.0006 & $0.0012 * * *$ \\
\hline UPFRONT_FEE & -0.0004 & 0.0000 & 0.0008 & -0.0004 & -0.0017 & 0.0025 & -0.0031 & $0.0019 * *$ & -0.0012 & 0.0001 \\
\hline ANNUAL_FEE & -0.0006 & -0.002 & 0.0001 & 0.0013 & -0.0003 & -0.001 & 0.0015 & $-0.0102 * *$ & -0.0006 & -0.0019 \\
\hline COMMITMENENTFEE & $0.008^{*}$ & -0.0081 & -0.0007 & 0.0043 & -0.0026 & 0.0064 & $0.0142 *$ & 0.0044 & 0.0027 & 0.0000 \\
\hline MATURITY & 0.0000 & 0.0001 & 0.0000 & 0.0002 & -0.0001 & 0.0002 & -0.0001 & $0.0001 *$ & 0.0000 & 0.0001 \\
\hline SECURED_YES & 0.0465 & 0.1932 & -0.0041 & -0.3394 & 0.3198 & -0.275 & 0.0592 & 0.3217 & $0.2176^{* *}$ & $-0.2286^{*}$ \\
\hline LOAN_REV̄OLVER & -0.1425 & 0.0791 & -0.2832 & 0.0068 & -0.6078 & -0.5522 & -0.0784 & $-0.5249 * *$ & -0.0286 & $-0.5646 * * *$ \\
\hline LOAN_TERM & 0.1006 & -0.066 & -0.0714 & 0.0553 & $-0.9738^{*}$ & -0.406 & 0.5448 & $-0.7602 * *$ & -0.0228 & $-0.8126 * * *$ \\
\hline REFINANCING_YES & -0.123 & 0.0807 & $0.164 * * *$ & 0.0245 & 0.4394 & -0.1269 & 0.0286 & -0.0913 & -0.1043 & -0.0653 \\
\hline FINANCIAL_CŌVENANT & -0.181 & -0.1162 & 0.013 & -0.258 & 0.5009 & 0.1342 & 0.0001 & 0.0001 & -0.0026 & $0.2659 * *$ \\
\hline NONFINANCIAL_COVENANT & 0.1896 & 0.2326 & 0.0498 & 0.1486 & -0.3286 & 0.1921 & 2.2903 & -0.1561 & -0.062 & 0.0968 \\
\hline PPC & $0.3073^{* * *}$ & 0.0873 & -0.0594 & 0.0476 & -0.2685 & 0.1941 & $0.3173^{*}$ & $0.454 * *$ & $0.1313^{* * *}$ & 0.0614 \\
\hline NUMBSYN & 0.0058 & -0.0028 & -0.0011 & -0.0046 & -0.0094 & 0.0052 & 0.0104 & $0.0094 *$ & -0.0028 & $0.0074 * * *$ \\
\hline PURPOSE_CHANGE_OF_CONTROL & 0.0038 & -0.0244 & -0.0119 & 0.1687 & 0.3254 & 0.1264 & 0.0718 & $-0.3418^{*}$ & 0.0463 & $-0.1876^{* *}$ \\
\hline PURPOSE_ONGOING_BUSINESS & -0.147 & $0.3422 *$ & -0.0044 & $0.3748^{*}$ & $-0.9367 * *$ & $0.3151 *$ & 0.1273 & 0.0687 & 0.0679 & $-0.2225^{* *}$ \\
\hline$\overline{\text { Adjusted- } \mathrm{R}^{2}}$ & 0.6176 & 0.6056 & 0.6964 & 0.4898 & 0.2758 & 0.7113 & 0.6188 & 0.4529 & 0.5577 & 0.6337 \\
\hline$N$ & 194 & 194 & 194 & 194 & 167 & 194 & 194 & 194 & 194 & 194 \\
\hline
\end{tabular}


Table XII. Granger Causality Tests With Facility-Specific and Borrower-Specific Controls. We repeat the Granger tests reported in Tables VII with loan facility-and borrower-specific control variables. Each model is estimated twice: restricted, through excluding the variables $R S_{t-1}$ and $R B_{t-1}$ from equations (3) and (4), respectively, and unrestricted where these variables are not excluded. We then compare the sum of squared residuals for the unrestricted and restricted models, and conduct $F$-tests and asymptotically equivalent tests of the null hypothesis that $\beta_{2}=0$. Significance denotes a finding of Granger causality. Test results are reported for portfolios formed using the following subsamples of observations: Loan observations with quotes below (low loan quotes) or above (high loan quotes) the median; loan observations with loan quote spreads below (low loan spreads) or above (high loan spreads) the median; loans with price below $\$ 70$ (distressed loans) or above $\$ 90$ (par loans); loans and without financial covenants; and observations with equity volume below (low equity volume) or above (high equity volume) the median. Controls include $R M_{t} R M_{t-1} R M_{t-2} R L_{t} R D_{t} Y_{t} N B A_{t} S P R D_{t} V_{t}$ prob kmv lnMV LNDEBT LEVERAGE INCOMETOA EPS pennystock ARATE BRATE CRATE LNDEALSIZE LNFACILITYSIZE LSPREAD UPFRONT_FEE ANNUAL_FEE COMMITMENT_FEE MATURITY SECURED_YES LOAN_REVOLVER LOAN_TERM REFINANCING_YES FINANCIAL_COVENANT NONFINANCIAL_COVENANT PPC NUMBSYN PURPOSE_CHANGE_OF_CONTROL PURPOSE_ONGOING_BUSINESS. Variable definitions are as follows: $R B_{t}$ is the loan return. $R S_{t}$ is the equity return. $R M_{t}$ is the equity index return. $R D_{t}$ is the T-Bill return. $Y_{t}$ is the year of the observation. $N B A_{t}$ is sum of the number of bids and asks for the loan. $S P R D_{t}$ is the difference between average ask and average bid, divided by the average of these two values. $V_{t}$ is the volume of trades on the equity market. PROB KMV is the implied probability of default on the date of the observation. LNMV is the natural logarithm of the borrower's market value on the date of the observation. LNDEBT is the natural logarithm of the borrower's debt for the year of the observation. LEVERAGE is the borrower's ratio of total debt to total assets for the year of the observation. INCOMTOA is the borrower's ratio of operating income before depreciation to total assets for the year of the observation. EPS is the borrower's earning per share for the year of the observation. PENNYSTOCK is an indicator variable that is equal to unity if the price of the borrower's stock is less than $\$ 1$ on the date of the observation. ARATE, BRATE, and CRATE are indicator variables that are equal to unity if the debt rating is between A3 and Aaa, B3 and Baa1, and C and Caa, respectively, and zero otherwise. LNDEALSIZE and LNFACILITYSIZE are the natural logarithm of the deal and facility size, respectively. LSPREAD is the basis point coupon spread over LIBOR plus the annual fee and upfront fee, spread over the life of the loan. UPFRONT FEE is the upfront fee, ANNUAL_FEE is the annual fee, and COMMITMENT_FEE is the commitment fee charged on unused portions of the loan. MATURITY is the number of days until the loan facility matures, as specified at initiation. SECURED YES is an indicator variable equal to unity if the facility is designated as securitized. LOAN_REVOLVER and LOAN_TERM are indicator variables that are equal to unity if the loan is a revolver or term loan, respectively. REFINANCING YES is an indicator variable that is equal to unity if the loan facility is designated as being for refinancing. FINANCIAL COVENANT is an indicator variable that is equal to unity if there are any of several financial covenants associated with the loan facility. NONFINANCIAL COVENANT is an indicator variable that is equal to unity if there are any of several nonfinancial covenants associated with the loan facility. PPC is an indicator variable that is equal to unity if the loan facility has a performance pricing covenant. NUMBSYN is the number of lenders in the syndicate providing the loan. PURPOSE_CHANGE_OF_CONTROL is an indicator variable is an indicator variable that is equal to unity if the purpose of the loan is as an acquisition line, IPO related, associated with a Leveraged Buyout or Management Buyout, spinoff related, or takeover related. PURPOSE ONGOING BUSINESS is an indicator variable that is equal to unity if the purpose of the loan is for CP backup, capital expenditure, corporate purposes, debtor in possession, or working capital. $* * *, * * *$ denote significance at the $1 \%, 5 \%$ and $10 \%$ levels, respectively. 
Panel A. Loan Return Dependent Variable. . Significance denotes that lagged weekly equity returns Granger cause weekly loans returns.

\begin{tabular}{|c|c|c|c|c|c|c|c|c|c|c|}
\hline Variable & $\begin{array}{l}\text { Low number } \\
\text { of loan } \\
\text { quotes }\end{array}$ & $\begin{array}{c}\text { High number } \\
\text { of loan } \\
\text { quotes }\end{array}$ & $\begin{array}{c}\text { Low loan } \\
\text { spreads }\end{array}$ & $\begin{array}{c}\text { High loan } \\
\text { spreads }\end{array}$ & $\begin{array}{l}\text { Distressed } \\
\text { loans } \\
\text { (Price }<=70)\end{array}$ & $\begin{array}{c}\text { Par loans } \\
(\text { Price }>=90)\end{array}$ & $\begin{array}{c}\text { Loans with } \\
\text { financial } \\
\text { covenants }\end{array}$ & $\begin{array}{c}\text { Loans without } \\
\text { financial } \\
\text { covenants }\end{array}$ & $\begin{array}{l}\text { Low equity } \\
\text { volume }\end{array}$ & $\begin{array}{l}\text { High equity } \\
\text { volume }\end{array}$ \\
\hline & (1) & (2) & (3) & (4) & (5) & (6) & (7) & (8) & (9) & (10) \\
\hline Number of Observations & 194 & 194 & 194 & 194 & 167 & 194 & 194 & 194 & 194 & 194 \\
\hline SSE restricted & 0.0005 & 0.0007 & 0.0000 & 0.0015 & 0.2228 & 0.0001 & 0.0005 & 0.0026 & 0.0006 & 0.0007 \\
\hline SSE unrestricted & 0.0005 & 0.0007 & 0.0000 & 0.0014 & 0.2098 & 0.0001 & 0.0005 & 0.0025 & 0.0006 & 0.0007 \\
\hline$F$-test & $6.3948^{* *}$ & $11.9019 * * *$ & 0.8441 & $9.7168 * * *$ & $10.1922 * * *$ & 0.5822 & $7.2902 * * *$ & $2.888^{*}$ & 1.0864 & $3.7903 *$ \\
\hline Asymptotically equivalent test & $6.4953 * *$ & $12.0889 * * *$ & 0.8573 & $9.8694 * * *$ & $10.3787 * * *$ & 0.5914 & $7.4047 * * *$ & $2.9334 *$ & 1.1035 & $3.8498 * *$ \\
\hline
\end{tabular}

Panel B. Equity Return Dependent Variable. Significance denotes that lagged weekly loan returns Granger cause weekly equity returns.

\begin{tabular}{|c|c|c|c|c|c|c|c|c|c|c|}
\hline Variable & $\begin{array}{c}\text { Low number } \\
\text { of loan } \\
\text { quotes }\end{array}$ & $\begin{array}{c}\text { High number } \\
\text { of loan } \\
\text { quotes }\end{array}$ & $\begin{array}{c}\text { Low loan } \\
\text { spreads }\end{array}$ & $\begin{array}{c}\text { High loan } \\
\text { spreads }\end{array}$ & $\begin{array}{c}\text { Distressed } \\
\text { loans } \\
(\text { Price }<=70)\end{array}$ & $\begin{array}{c}\text { Par loans } \\
\text { (Price }>=90)\end{array}$ & $\begin{array}{c}\text { Loans with } \\
\text { financial } \\
\text { covenants }\end{array}$ & $\begin{array}{c}\text { Loans without } \\
\text { financial } \\
\text { covenants }\end{array}$ & $\begin{array}{c}\text { Low equity } \\
\text { volume }\end{array}$ & $\begin{array}{c}\text { High equity } \\
\text { volume }\end{array}$ \\
\hline & $(1)$ & $(2)$ & (3) & (4) & $(5)$ & $(6)$ & (7) & $(8)$ & (9) & $(10)$ \\
\hline Number of Observations & 194 & 194 & 194 & 194 & 167 & 194 & 194 & 194 & 194 & 194 \\
\hline SSE restricted & 0.3002 & 0.3219 & 0.1666 & 0.5302 & 7.3297 & 0.2155 & 0.2947 & 0.4109 & 0.1954 & 0.4543 \\
\hline SSE unrestricted & 0.2972 & 0.3193 & 0.1649 & 0.5258 & 7.3211 & 0.2155 & 0.2921 & 0.4100 & 0.1907 & 0.4540 \\
\hline$F$-test & 1.9703 & 1.5951 & 1.8866 & 1.587 & 0.1916 & 0.0035 & 1.6572 & 0.4091 & $4.7422 * *$ & 0.1622 \\
\hline Asymptotically equivalent test & 2.0012 & 1.6202 & 1.9163 & 1.612 & 0.1951 & 0.0036 & 1.6832 & 0.4155 & $4.8167 * *$ & 0.1648 \\
\hline
\end{tabular}

